\title{
EL ESTADO Y LOS PARTICULARES EN LA EDUCACIÓN CHILENA, 1888-1920
}

\author{
Juan Luis Ossa Santa Cruz
}

El estudio que sigue intenta iluminar algunos aspectos importantes de la relación entre el Estado y los particulares en el campo de la educación chilena en el período 1888-1920. Este lapso engloba una diversidad de fenómenos referentes a aquella relación — tanto en su vertiente ideológica como en su vertiente pragmática-, y una nada insignificante lista de los actores que, día a día, buscaban el progreso de la enseñanza nacional. El conflicto curricular de la década de 1890, las solicitudes y entregas de subvenciones a los establecimientos privados, y la lucha por la libertad de enseñanza, manifestada, entre otros, en el debate sobre la Ley de Instrucción Primaria Obligatoria de 1920, fueron los tres principales escenarios en que se expresó dicha relación, la cual sobrevivió incluso en los momentos más difíciles de aquella época. Esto confirmaría que el nexo entre el Estado y los particulares en la educación es mucho más antiguo de lo que comúnmente se cree, y que las transformaciones impuestas por el "neoliberalismo" en las últimas tres décadas no son más que una continuación de un largo proceso histórico, que, por lo demás, se había iniciado ya en los albores del siglo XIX.

JuAN LuIS OsSa SANTA CRUZ. Licenciado en historia por la Universidad Católica de Chile. Correo electrónico: juanluisossa@yahoo.com.

${ }^{1}$ Esta investigación contó con la valiosísima colaboración de Mónica Marín Reyes. Agradezco los comentarios y sugerencias del profesor Iván Jaksic y la ayuda de Andrés Baeza, Joaquín Fernández y Cristóbal García-Huidobro. 


\section{Introducción}

Una de las características del subdesarrollo es la identidad total del gobierno y el Estado. En Francia, Suecia o Inglaterra

una empresa pública conserva cierta autonomía del poder político; pertenece al Estado y su administración,

su personal y su funcionamiento están más o menos a salvo de abusos gubernamentales. Pero en un país subdesarrollado, ni más ni menos que en un país totalitario, el gobierno es el Estado. Mario Vargas Llosa (El Pez en el Agua).

\section{E} l interés por la historia de la educación en Chile ha existido prácticamente desde los inicios de nuestra vida colonial. Cronistas, investigadores y educadores han llenado páginas enteras sobre las características y particularidades de la enseñanza, contribuyendo con ello a la extensión y profesionalización del conocimiento. Obviamente, las preguntas y respuestas elaboradas por los intelectuales han dependido del contexto histórico de cada época. Por eso, más de alguna vez los estudios sobre educación han estado subordinados a principios ideológicos antes que a consideraciones prácticas, y, por ende, muchos debates se han eternizado en discusiones poco efectivas. No obstante, también se han dado casos en que la contribución ha sido real y constructiva, hasta el punto de que, en más de una ocasión, la toma de decisiones ha estado influenciada por ellos.

Teniendo esto en cuenta, parece evidente señalar que el tema requiere nuevas miradas e interrogantes, aunque ahora iluminadas por las necesidades de nuestro tiempo. Economistas, sociólogos, sicólogos e historiadores — por nombrar sólo unos pocos - tienen ante sí la oportunidad de enriquecer con sus diferentes perspectivas la “cuestión educacional”, planteando dudas y soluciones de interés general.

Algunas de éstas fueron recientemente puestas en la palestra luego de que los estudiantes secundarios realizaran en 2006 una movilización nacional, que, a juzgar por su acabada planificación, se habría ido incubando a lo largo de varios años. Como resultado de ese movimiento, se reabrieron diferentes temas. Uno de los más recurrentes fue la relación entre el Estado y la educación particular, con especial énfasis en la subvención fiscal y la iniciativa privada. Algunos políticos e intelectuales alzaron sus voces pidiendo y dando explicaciones sobre esa relación, y, en general, se llegó a la conclusión de que aquélla había comenzado hace solamente tres décadas, 
es decir, cuando el “neoliberalismo” económico hizo su aparición. ¿Cuán cierta es esta afirmación?

Un análisis histórico más o menos prolijo nos entrega una visión que contradice diametralmente dicha afirmación. En efecto, una amplia gama de documentos confirman que el interés del Estado republicano por la educación particular había comenzado ya en una época tan temprana como la década de 1820, profundizándose más o menos regularmente a lo largo de la centuria.

Esto no quiere decir que la conexión entre el Estado y los particulares en materia educacional no haya estado sometida a vaivenes y dificultades durante esos años. Quizás el conflicto más explícito haya sido la discusión ideológica sobre la libertad de enseñanza, iniciada en la década de 1870. A la sazón, el debate giró en torno a la relación Iglesia-Estado, simbolizada en cuál autoridad debía tener la potestad de examinar a los estudiantes particulares: el ministerio o los privados. Por motivos coyunturales y estratégicos, los católicos abogaron por la libertad de la toma de exámenes y por su propia metodología de enseñanza, la que, en la mayoría de los casos, se oponía a la educación que impartían los centros laicos. Los liberales, en cambio, pretendieron controlar todos los temas educacionales desde el Estado, ya fuera mediante decretos gubernamentales o a través de legislación aprobada por el Congreso.

Otro plano de discusión giró alrededor de las subvenciones gubernamentales a los colegios particulares. Sin embargo, a diferencia de lo que ocurría con la examinación y con los sistemas de enseñanza, esta cuestión no solía generar divisiones entre los políticos, ya que comprendían que muchas veces los colegios subvencionados satisfacían demandas que al Estado se le hacía imposible cubrir. Esto permitía que el número de subvenciones fuera bastante alto. Entre ellas, habría que destacar las que, año a año, recibían —entre otras- las escuelas indígenas regentadas por misioneros en la Araucanía, los liceos femeninos de educación secundaria de Santiago y los colegios regionales, establecimientos, todos, que utilizaban diferentes estrategias para dar a conocer la calidad de la educación que impartían, y, por consiguiente, cuánto esperaban recibir por parte del gobierno.

Estos dos ámbitos de la relación entre el Estado y los particulares en la educación se profundizaron a fines de la década de 1880, cuando el fisco comenzó a gastar cada vez más en la educación pública y en la subvencionada. Los ingresos reportados por las salitreras ayudaron a que las condiciones de los colegios e institutos mejoraran, pero también a que los gobiernos de turno alcanzaran una influencia nunca antes vista. 
Ello trajo como resultado que los conservadores renovaran su oposición a la examinación oficial, aunque ahora criticando abiertamente el método concéntrico de enseñanza impuesto por los políticos liberales y radicales durante la década de 1890. Al mismo tiempo, la influencia estatal provocó una polémica parlamentaria en torno a un nuevo proyecto de ley que proponía modificar profundamente la instrucción primaria obligatoria, materia en que católicos y radicales se enfrentaron. No obstante, en ambos casos el espíritu de negociación fue el que finalmente imperó, ya que todos los sectores políticos lograron sortear algunas de sus diferencias y conseguir que sus propósitos se convirtieran en realidad. En ese sentido, las diferencias entre lo público y lo privado no siempre eran evidentes, sino que muchas veces las aspiraciones e ideales de unos y otros se entrecruzaban y se complementaban.

Las tres décadas que cubren desde la creación de la Universidad Católica en 1888 hasta la promulgación de la Ley de Instrucción Primaria Obligatoria de 1920, han servido de referente y de marco temporal para el estudio que sigue a continuación. Hemos elegido este lapso por dos razones: la primera, porque muchos análisis sobre educación han concentrado su principal atención en el periodo anterior o, en contraposición, en el inmediatamente posterior, dejando de lado algunos aspectos claves de la relación forjada entre ambos sectores a fines del siglo XIX y principios del XX. La segunda, y muy ligado a la anterior, porque el estudio de estos años permite formarse una visión más o menos global de los distintos escenarios en que se concretó dicho fenómeno, ya sea en su vertiente ideológica como en la práctica. Con esto, nos propusimos responder algunas preguntas sobre la conexión entre el Estado y la instrucción privada durante esos años, dedicándonos a cuatro aspectos importantes de ella.

Por un lado, y a modo de preámbulo, revisaremos algunos aspectos bibliográficos de la relación entre el Estado y los particulares durante la “república temprana”, esto es, entre 1810 y 1874.

Por otro, estudiaremos los conflictos políticos más importantes que protagonizaron conservadores, liberales y radicales en lo tocante a la cuestión educacional, específicamente en lo referente a los métodos de enseñanza.

A su vez, en los apartados 3 y 4 analizaremos los sistemas de subvenciones, tanto en la fase de solicitud como en la de otorgamiento. En ellos, confirmaremos que la ayuda económica dependía de diversas circunstancias, pero que, en general, el Estado no ponía mayores obstáculos cuando constataba que los colegios subvencionados cubrían una necesidad que al erario se le hacía imposible subvenir por sí sola. Además, veremos que 
estas subvenciones ayudaban preferentemente a la oferta educacional, pero también a la demanda estudiantil mediante la entrega de becas.

Finalmente, fijaremos nuestra atención en la discusión ideológica que surgió en el Congreso Nacional en el curso de la Ley de Instrucción Primaria Obligatoria, en cuyos años (1902-1920) los políticos se abocaron nuevamente a discutir la libertad de enseñanza y el papel del Estado y los particulares en la educación.

Con estos antecedentes, intentaremos demostrar que, a pesar de ser diferentes, las tres últimas cuestiones se dieron simultáneamente, y que el vínculo entre el Estado y los privados durante 1888 y 1920, siendo muy complejo, subsistió incluso en los momentos más conflictivos.

\section{El Estado y los particulares en el campo educacional chileno durante la "república temprana"} (1810-1874)

Ya que el Estado no puede con sus propios recursos proveer en toda su extensión a las exigencias de la enseñanza, provechoso es que proporcione estímulos y facilidades a los establecimientos de educación dirigidos por particulares.

Federico Errázuriz (Memoria del Ministro de Justicia, Culto e Instrucción Pública, Anales de la Universidad de Chile, 1865).

Uno de los primeros objetivos de los gobiernos chilenos luego de las guerras de independencia, fue construir un sistema educacional acorde con las ideas que habían inspirado el movimiento revolucionario de 1810. Para los intelectuales y militares de aquella época, la educación era una herramienta de primer orden para llevar a cabo el propósito fundamental que había inspirado a algunos sectores de la Ilustración: la creación del ciudadano republicano. Cualquier proyecto que buscara la concretización de este sueño era apoyado por los referentes más avanzados de la emancipación, como también lo eran los intentos por incrementar el acceso a la educación y mejorar la enseñanza.

La creación del Instituto Nacional (IN) en 1813 fue un paso significativo en esta cruzada, convirtiéndose rápidamente en el centro educacional por excelencia de la elite criolla. Al mismo tiempo, algunos gobiernos comenzaron a ayudar a los particulares que mostraban interés en fortalecer la 
enseñanza privada, sin que ello significara necesariamente un conflicto con el auxilio que entregaban a los establecimientos públicos.

Hombres como Francisco Antonio Pinto, vicepresidente del país entre 1827 y 1829, fomentaron la educación particular por medio de la asignación de fondos fiscales a individuos que mostraban idoneidad y confiabilidad. Así ocurrió, por ejemplo, con el español José Joaquín de Mora, avecindado en Chile desde febrero de 1828, quien contó con el explícito apoyo de la administración Pinto para fundar el Liceo de Chile. Este colegio se instaló en un predio fiscal ubicado en el "cuartel de Maestranza”, cuyo canon de arrendamiento se entendía cubierto si el Liceo recibía "gratuitamente [a] diez jóvenes [hombres] agraciados por el gobierno"2.

Aunque es cierto que este primer intento por generar un vínculo estable entre el Estado y los privados en la educación chilena sufrió altos y bajos $^{3}$, la estrategia de combinar el dinero estatal con el servicio que prestaban los particulares funcionó relativamente bien durante los decenios 18311861.

Así, en el gobierno de Joaquín Prieto se inspeccionó por primera vez a los establecimientos privados, intentándose uniformar la educación particular con la pública ${ }^{4}$. Lo que se buscaba era tener un recuento exacto de sus métodos de enseñanza, "réjimen interior, castigos, premios y en jeneral cuanto creyeren conducente a la mejora de la educación”, y, de ese modo, determinar a ciencia cierta a qué establecimientos privados auxiliar. Lo más importante de esta medida no fue un aparente afán estatal por controlar la educación, sino lograr que la calidad de la enseñanza ofrecida por los sostenedores privados fuera el eje articulador de la relación entre el Estado y los particulares.

El interés de la administración Prieto se debió también a que el número de escuelas públicas era bastante menor que el de las particulares, cuestión que movía al gobierno a ser solícito con las necesidades económicas que éstas demostraran. En efecto, “al terminarse la administración del general Prieto, no había en toda la república más que cincuenta y seis modestísimas escuelas públicas sostenidas por el Estado"6. Por otra parte, en 1843, bajo el gobierno de Manuel Bulnes, un cuadro informativo señalaba que en

\footnotetext{
${ }^{2}$ Barros Arana, Diego: Historia General de Chile, 2005, tomo XV, p. 219.

${ }^{3}$ Véase ibídem.

${ }^{4}$ Véase ibídem, p. 57.

${ }^{5}$ Citado por Serrano, Sol: Universidad y Nación. Chile en el Siglo XIX, 1993, p. 57.

${ }^{6}$ Barros Arana, Diego: Un Decenio de la Historia de Chile (1841-1851), 2003, tomo I, p. 233.
} 
Santiago existían 78 escuelas primarias, de las cuales 60 eran absolutamente particulares, y el resto pertenecía a municipios, conventos y parroquias ${ }^{7}$.

Estos datos comprueban que, por lo menos en cantidad, la presencia de los particulares en la educación primaria capitalina era más evidente que la del Estado. Quizás por esta razón, Bulnes y sus ministros se esforzaron en extender la enseñanza pública en general y, con ello, el poder del Estado dentro del sistema educacional. El paso más significativo fue, sin dudas, la creación de la Universidad de Chile $(\mathrm{UCH})^{8}$, aunque también se fundaron otros establecimientos fiscales, como la Escuela de Bellas Artes y la Quinta Normal de Agricultura ${ }^{9}$. Este tipo de instituciones permitió que la estructura estatal afianzara su influencia, y que lograra un grado de intervención bastante significativo. Gracias a ello, nació el denominado Estado docente, cuyos propósitos se reflejaron, preferentemente, en la formulación de los contenidos educacionales y en la obligatoriedad de la examinación oficial de los educandos ${ }^{10}$.

Ahora bien, contrariamente a lo que podría pensarse, esta subordinación de los particulares no pareció ofender ni molestar a nadie durante esos años. La explicación de este fenómeno reside, entre otras cosas, en que gobiernistas y opositores recordaron (y aceptaron) que la Constitución de 1833 declaraba que "la educación pública [era] una atención preferente del Gobierno"11, y que, como dice Sol Serrano, la examinación oficial, fijada en una ley de 1842, era una "herramienta fundamental para la racionalización del orden interno del sistema educacional” antes que un "control doctrinario" ${ }^{2}$. En ese sentido, la supremacía del Estado fue vista como una condición sine qua non de la enseñanza nacional, "tanto por voluntad de los hombres que [la] concibieron, como por obra de las circunstancias en que hubo de ensayar sus primeros pasos”13.

\footnotetext{
${ }^{7}$ Véase ibídem, tomo I, nota al pie, p. 233. Barros Arana separa tanto a las escuelas municipales como a las religiosas del grupo de las "particulares", aunque lo cierto es que, estrictamente hablando, éstas deberían ser consideradas como tales. Así lo serán de aquí en adelante en nuestro artículo.

${ }^{8}$ Véase, entre otros, Serrano, Sol: Universidad y Nación..., 1993, y Jaksic, Iván: Andrés Bello: La Pasión por el Orden, 2001, pp. 156-163.

${ }^{9}$ Véase Barros Arana, Diego: Un Decenio de la Historia de Chile..., 2003, tomo II, capítulo 5.

${ }^{10}$ Un muy buen análisis sobre la confección de los contenidos educacionales en Chile, sobre todo lo que se refiere a la enseñanza de las humanidades, se encuentra en Cruz, Nicolás: El Surgimiento de la Educación Secundaria Pública en Chile. 18431876 (El Plan de Estudios Humanista), 2002, capítulos II y III.

${ }^{11}$ Artículo 153 de la Constitución Política de Chile de 1833, en www.memoriachilena.cl.

${ }^{12}$ Serrano, Sol: Universidad y Nación..., 1993, p. 222.

${ }^{13}$ Labarca, Amanda: Historia de la Enseñanza en Chile, 1953, p. 131.
} 
Esta aceptación de los particulares ayudó a que el Estado continuara apoyando a los centros privados. Más todavía, según Amanda Labarca, en esa época "los creadores del estado docente, sobre todo [Manuel] Montt y [Antonio] Varas, dejaron a la enseñanza particular una amplísima libertad; más aun, fomentaron la venida a Chile de nuevas órdenes enseñantes”14, entre las cuales destacaron los jesuitas, que regresaron triunfantes luego de su expulsión en 1767. En efecto, con el beneplácito del presidente Montt, en 1854 se puso la primera piedra del Colegio San Ignacio, que con el tiempo llegaría a ser uno de los colegios particulares más importantes del país.

De esta manera, durante los tres primeros decenios, la educación particular recibió un significativo auxilio estatal. Sin embargo, las buenas relaciones entre el Estado y los privados no podían durar para siempre, y, ya para fines de la década de 1850, se vislumbraron los primeros conflictos entre ambos. ¿El motivo? Los políticos y educadores contrarios al gobierno de Montt comenzaron a cuestionar las bases del Estado docente, y a sostener que la "amplísima libertad” educacional a la que haría mención Amanda Labarca un siglo después, no era tal.

Para los opositores, la libertad de enseñanza no debía descansar únicamente en el permiso estatal para construir o fundar establecimientos privados, sino que debía extenderse hasta el punto de que los particulares pudieran examinar independientemente a sus estudiantes en sus respectivos establecimientos. Con ello, pretendían que el Estado no continuara interviniendo en los contenidos de la enseñanza, ni que la examinación oficial —impuesta, como decíamos, en 1842 - fuera el único mecanismo de evaluación al finalizar el año escolar. ¿Qué había sucedido? ¿Por qué la intervención estatal empezaba a ser cuestionada por algunos sectores de la sociedad chilena? ¿Qué había hecho cambiar el parecer de la oposición con respecto a la examinación?

A nuestro entender, el cambio de mentalidad de los opositores al gobierno se debió a las estructuras de la relación Iglesia-Estado. Ambos habían convivido relativamente bien a lo largo del siglo XIX, aunque en ciertas ocasiones las diferencias de opinión respecto a algunos temas específicos los habían dividido. El más importante de estos temas hacía referencia al grado de injerencia que podía y debía tener el poder civil en las decisiones de la Iglesia. Los gobiernos insistían que al Estado le correspondía ejercer el Patronato. La Iglesia, en tanto, se defendía argumentando que aquel derecho le pertenecía exclusivamente al Papa y a sus delegados arzobispales, y que, por tanto, el poder civil no debía involucrarse en las decisiones de Roma.

\footnotetext{
${ }^{14}$ Ibídem.
} 
Las diferencias entre estas posturas empezaron a evidenciarse luego de que el gobierno de Manuel Montt se enfrentara al arzobispo Rafael Valentín Valdivieso por la tan conocida “cuestión del sacristán”15. La principal consecuencia de este conflicto fue la creación de una alianza conformada por los católicos ultramontanos y los liberales que se oponían a Montt. La Fusión Liberal-Conservadora, fruto de esta coalición, llevó a la primera magistratura a José Joaquín Pérez en 1861, y más tarde a Federico Errázuriz, dividiéndose los ministerios en partes semejantes y soportando más o menos bien las dificultades políticas del periodo.

No obstante, las bases de esta alianza coyuntural eran demasiado débiles para capear las discrepancias doctrinales, una de las cuales se refería al papel del Estado y de los particulares en la educación. El grupo liberal, encabezado por intelectuales como Diego Barros Arana y los hermanos Amunátegui, creían que la intervención estatal en la enseñanza debía ser completa. Mediante argumentos constitucionales, sostenían que los contenidos de las materias y los exámenes eran responsabilidad directa de la UCH y del IN, por lo que los privados poco y nada podían intervenir en ellos. Además, postulaban que "la enseñanza religiosa a nivel secundario debía ser voluntaria" y que los disidentes tenían derecho a "fundar sus propias escuelas" 16 .

Los conservadores ultramontanos, en tanto, consideraban que el anticlericalismo de los sostenedores del sistema estatal influía negativamente en el devenir de la sociedad chilena, y estaban dispuestos a llegar a las últimas consecuencias para hacer prevalecer su metodología de enseñanza en los colegios católicos, incluso con la aspiración de que ella se extendiera a los demás centros educacionales del país. Por esta razón, en 1871, al asumir las carteras que le correspondían en el gobierno liberal de Federico Errázuriz, el Partido Conservador comenzó una lucha, ahora desde el seno del poder, a favor de la libertad de enseñanza y de examinación. El principal protagonista de esta ardua cruzada fue Abdón Cifuentes, a la sazón ministro de Instrucción Pública, quien, mediante un decreto de 1872, sustrajo "los exámenes de los colegios particulares de la fiscalización del Estado"17.

Las conversaciones entre Cifuentes y Errázuriz para que éste decretara la libertad de enseñanza comenzaron en 1871, al momento de iniciarse la

\footnotetext{
${ }^{15}$ Véase, entre otros, Collier, Simon: Chile: The Making of a Republic, 18301865. Politics and Ideas, 2003, pp. 199-205, y Moscoso, Pablo: "La Cuestión del Sacristán: Historia en Diez Actos”, 2006, pp. 131-160.

${ }^{16}$ Serrano, Sol: Universidad y Nación ..., 1993, p. 221.

${ }^{17}$ Ibídem.
} 
nueva presidencia. Al respecto, Cifuentes cuenta en sus Memorias cómo negoció su designación para el ministerio y cuáles fueron sus exigencias para aceptar el cargo. En un diálogo con Errázuriz, le dijo:

\begin{abstract}
Yo, señor, quiero la libertad de la enseñanza, repruebo su monopolio y, sobre todo, el monopolio minucioso de los exámenes de cada ramo de estudio que tiene el Instituto Nacional, monopolio que no existe ni en Francia, que ha sido la moderna inventora del monopolio del Estado en la enseñanza. Hace años que en la prensa y en privado vengo pidiendo siquiera la libertad de esos exámenes como en Francia; que se reduzca el monopolio siquiera a los exámenes de los grados universitarios, es decir, de Bachiller y Licenciado; y siempre he encontrado en los liberales del Consejo de Instrucción, como Barros Arana y Amunátegui, y en los profesores del Instituto, que son los usufructuarios de ese monopolio que constituye la vaca lechera de su prestigio y de sus granjerías pecuniarias, la más tenaz oposición a toda libertad. [...]
\end{abstract}

Errázuriz le habría replicado de la siguiente forma: "Está salvada la dificultad. [...] Algunos me han hablado de separar a Diego Barros del Instituto. ¿Qué piensa usted?”:

'Creo que sería una medida odiosa; yo no quiero hostilizar a nadie. Para mí la cuestión de personas es muy insignificante; lo que me interesa es la libertad, son los principios; denme la libertad y quédense con sus empleos. Barros se ha hecho odioso, no tanto por sus ideas irreligiosas, como por el poder absoluto e irresponsable que tiene en la enseñanza, gracias al monopolio de que dispone y a la manera despótica con que ejercita su poder. Suprima ese poder y se calmarán los odios. Que quede Barros en su rectorado; pero deme la libertad y la igualdad en los exámenes. Eso es lo que importa al país y a las ciencias' ${ }^{18}$.

Para los conservadores, la educación de la juventud era responsabilidad exclusiva de los padres de familia ${ }^{19}$. Según el arzobispado, los católicos tenían el deber y el derecho de elegir para sus hijos la enseñanza que más les acomodara, sin estar sometidos a la regulación de un Estado que, para ellos, era cada vez más laico e irreligioso. Si los establecimientos católicos dependían de ese Estado, entonces los padres creyentes no estaban

${ }^{18}$ Cifuentes, Abdón: Memorias, 1936, tomo I, pp. 405-406.

${ }^{19}$ Véase Serrano, Sol: Universidad y Nación..., 1993, p. 233. 
siendo respetados en sus derechos. Por eso, para hombres como Cifuentes, el Estado docente era ilegal en su esencia, ya que, al igual que cualquier monopolio, no aseguraba el principio básico de una sociedad que se decía democrática: la libertad.

Pero había algo que aún no estaba del todo claro: ¿por qué a los denominados “liberales”, como Barros Arana y Amunátegui, se les consideraba los paladines del estatismo y del monopolismo educacional? ¿Por qué razón los “conservadores” se autoproclamaban los sostenedores del "verdadero" liberalismo chileno?

La razón estriba en que la discusión sobre "liberalismo” y “conservadurismo” en esa época respondía, antes que todo, a un trasfondo religioso, en el que las definiciones ideológicas estaban teñidas por el proceso de secularización de la sociedad. Los “liberales” de 1870 creían en la libertad de cultos y en el matrimonio civil, pero eran contrarios a la libertad de enseñanza. Los “conservadores”, por otro lado, podían estar a favor de la libertad de enseñanza, aunque eran reticentes a la libertad de cultos. Es decir, ambos grupos utilizaban el liberalismo para sus propios fines, confirmando que su principal objetivo era hacer prevalecer sus respectivas ideas sobre el tipo de sociedad que pretendían construir.

Ahora bien, y a pesar de esta suerte de utilización pragmática o instrumental de las doctrinas liberales, no cabe duda que la discusión ideológica de la década de 1870 trajo como resultado una mayor apertura en la educación nacional. Es cierto que el decreto de 1872 fue suspendido dos años después por el nuevo ministro de Instrucción Pública, el liberal José María Barceló, y que, más aún, la Fusión Liberal-Conservadora dejó de existir. Pero, paradojalmente, también es efectivo que, el 13 de agosto de 1874, se agregó un inciso a la Constitución de 1833 en el que se declaraba la "libertad de enseñanza"20.

Además, ese mismo año se aceptó que “aquellos establecimientos que impartían el programa secundario completo [...] podían tomar los exámenes en sus establecimientos por una comisión formada por dos miembros nombrados por el Consejo Universitario y un tercero por el colegio"21, cuestión que nos hace pensar que el liberalismo del Partido Conservador no fue del todo rechazado por los políticos de entonces. De una u otra forma, toleraron las aspiraciones conservadoras en pos de la libertad de enseñanza.

¿Cuánto perduraría esta tolerancia?

${ }^{20}$ Inciso $6^{\circ}$ del artículo 12 de la Constitución Política de Chile de 1833, en www.memoriachilena.cl.

${ }^{21}$ Serrano, Sol: Universidad y Nación..., 1993, p. 238. 


\title{
2. ¿Cómo educar? \\ El sistema concéntrico y la propuesta católica
} (1879-1913)

\author{
A la[s] Escuela[s] fiscal[es] [...] \\ las salvan sus métodos de enseñanza. El buen \\ sentido popular ha comprendido la incomparable \\ superioridad de éstos sobre los empleados \\ en las escuelas católicas. \\ Revista de Instrucción Primaria \\ (Año XV, número 11, noviembre de 1901).
}

Es indispensable, pues, so pena de que desaparezca la fe religiosa adquirida en los primeros años, que el joven estudie los fundamentos racionales de su fe, los motivos de credibilidad; que adquiera la convicción íntima de que la fe no sólo no es adversaria ni antagonista de la razón, sino su mejor aliada; que sepa repeler los ataques y disipar las prevenciones y desvanecer los sofismas que se presentan en nombre de la ciencia. Y he aquí lo que encontrará en el estudio serio y razonado de los Fundamentos de la Fe.

La Revista Católica (número 122, 18 de agosto de 1906)

En 1879 se promulgó una nueva ley de educación, que daba espacio a que los particulares fundaran colegios primarios y secundarios ${ }^{22}$. No obstante, al mismo tiempo disponía que se controlara la examinación y el contenido curricular de la enseñanza, favoreciéndose la educación científica por sobre la filosófica-religiosa ${ }^{23}$ que había guiado, hasta entonces, a la enseñanza en general. Además, esta ley decretaba que la instrucción de la religión católica no sería obligatoria en los colegios secundarios estatales, y que "el examen de esos ramos o el certificado de haberlos rendido, no era obligatorio para obtener grados universitarios"24. Todo esto produjo un nuevo y explícito campo de enfrentamiento entre los particulares católicos y los representantes del Estado laico, el cual, con altos y bajos, se prolongaría hasta la segunda década del siglo XX.

${ }^{22}$ Véase ibídem, pp. 247-250.

${ }^{23}$ Véase Jaksic, Iván: Academic Rebels in Chile. The Role of Philosophy in Higher Education and Politics, 1989, p. 46, y Campos Harriet, Fernando: Desarrollo Educacional, 1810-1960, Santiago, 1960, pp. 80-82.

${ }^{24}$ Campos Harriet, Fernando: Desarrollo Educacional..., 1960, p. 83. 
Los católicos creían que de poco y nada servía que la reforma constitucional de 1874 garantizara la "libertad de enseñanza", si sólo cinco años después se confirmaba la obligatoriedad de la examinación oficial ${ }^{25}$. Su postura, empero, no descansaba únicamente en una cuestión constitucional, sino también en una razón curricular. Cualquier análisis que hiciera la Iglesia sobre el futuro de la educación pública llegaba a una misma conclusión: quien tuviera en sus manos la examinación, podría formular y reformular a su antojo los contenidos académicos. Así, pues, si el nuevo currículo era "cientificista”, entonces los exámenes de fin de año tendrían una connotación científica, y la enseñanza de la religión y de la filosofía escolástica no sería más que un mero adorno. Ahora bien, ¿a qué tipo de "ciencia" se refería la ley de 1879?, ¿estaba la Iglesia necesariamente en contra de la "ciencia”?

Los creadores de la ley de 1879, liderados por Miguel Luis Amunátegui, pertenecían a un grupo de intelectuales que, desde mediados del siglo XIX, habían dedicado su tiempo a combatir la influencia de la Iglesia, tanto en la sociedad civil como en la enseñanza. Para ello, habían tomado como referencia la obra académica de Auguste Comte, padre del positivismo francés, cuyo trabajo, aseguraban los "positivistas" chilenos, era una amenaza para los católicos de todo el mundo. Según José Victorino Lastarria, el positivismo demostraba que las creencias religiosas no eran ya dominantes, y que la tradición del Antiguo Régimen era contraria a la justicia social, porque obstruía "las leyes de la humanidad", esto es, la libertad y el progreso $^{26}$.

Diego Barros Arana también formaba parte de este círculo de políticos e intelectuales liberales que reunía a los positivistas chilenos, conocido como la Academia de Bellas Letras ${ }^{27}$. Su presencia no sólo enriquecía las discusiones sobre la influencia del positivismo en Chile, sino también daba pie a que los críticos de aquella filosofía, entre ellos Abdón Cifuentes, vieran en la Academia un centro de preparación irreligiosa, que podía influir negativamente en la enseñanza de la juventud chilena ${ }^{28}$.

${ }^{25}$ Como dice Campos Harriet, la ley de 1879 propició “dos principios al parecer contradictorios”, pero estatuidos legalmente. Por un lado, "la Constitución de 1833, como las anteriores y la Ley Orgánica de la Universidad de Chile [de 1842], establecían entre nosotros el principio del Estado docente. Es decir, expresan bien claro que el Estado tiene la obligación de enseñar. [...] Por otra parte, la reforma constitucional de 13 de agosto de 1874, aseguraba a todos los habitantes de la república la libertad de enseñanza”, en ibídem, p. 81.

${ }^{26}$ Véase Jaksic, Iván: Academic Rebels in Chile..., 1989, p. 43.

${ }^{27}$ Véase ibídem.

${ }^{28}$ Para no quedarse atrás, Cifuentes creó la Sociedad de Amigos, una suerte de contraparte de la Academia de Bellas Letras. Véase ibídem, p. 42. 
Las aprensiones de Cifuentes podían ser exageradas, aunque no cabe duda que nuestros positivistas pretendían llegar a tener el completo control de la educación nacional. Como acertadamente anota Iván Jaksic:

La razón de la reacción católica descansa tanto en el crecimiento sustancial de la influencia del positivismo en el país como en el hecho de que los positivistas hicieron un esfuerzo por transformar el currículo de los colegios chilenos. La educación fue el área donde mayormente se concentraron los positivistas, porque, por un lado, muchos de sus más distinguidos seguidores ocupaban posiciones de influencia en el sistema educacional, y, por otro, compartían con los católicos la creencia de que quien controlara el sistema educacional tenía mucho que decir en la formación de los valores y del carácter de la sociedad chilena ${ }^{29}$.

En efecto, católicos y positivistas —estos últimos, agrupados en liberales y radicales - compartían la aspiración de dominar la formación valórica de la sociedad, para lo cual era indispensable intervenir significativamente en los contenidos de la enseñanza.

El ejemplo del radical Valentín Letelier es uno de los más relevantes al momento de estudiar la puesta en práctica del "cientificismo" en Chile. Letelier había sido discípulo de Barros Arana en el IN, y a través de él había conocido las ideas de Comte y de otros intelectuales positivistas. Entre 1872 y 1875 había destacado como estudiante de leyes en la $\mathrm{UCH}^{30}$. En 1882, cuando el país se encontraba en medio de la Guerra del Pacífico, se embarcó en un viaje a Prusia, donde conoció el sistema educacional alemán. De él, sacó dos importantes conclusiones: en primer lugar, que los colegios prusianos disfrutaban de una amplia libertad religiosa, y, en segundo, que aquel sistema estaba compuesto por una "educación integral, esto es, una combinación de elementos intelectuales y prácticos en todos los niveles educacionales"31.

${ }^{29}$ Ibídem, p. 45. El original en el inglés dice: "The reason for the Catholic reaction lies as much in the substantial growth of positivistic influence in the country as in the fact that positivists mad an effort to transform the curriculum in Chilean schools. Education was the one area that positivists concentrated on the most because, on the one hand, many of their most distinguished followers occupied positions of influence in the educational system, and, on the other, they shared with Catholics the belief that whoever controlled the educational system had a significant say in shaping the values and character of Chilean society".

${ }^{30}$ Véase ibídem, p. 50.

${ }^{31}$ Ibídem, p. 51. El original en inglés dice: "an integral education, that is, a combination of intellectual and practical elements at all educational levels". 
Su pensamiento quedó plasmado definitivamente en su Filosofía de la Educación, obra que publicó en 1891, aunque sus ideas podían vislumbrarse ya en la década anterior ${ }^{32}$. Letelier intentó extrapolar a Chile la teoría comteana de los tres estados sociales. Recordemos que Comte entendía el progreso de la humanidad como una sucesión de etapas, comenzando en un estado teológico, continuando en un estado metafísico y concluyendo en un estado científico, el cual era la culminación perfecta a la que debían aspirar las sociedades contemporáneas. Como intelectual, Letelier adhirió a este modelo, y lo utilizó con el fin de explicar la evolución histórica y las falencias de la educación nacional. Según él, el estado científico, en contraposición al resto, era el único que podía rescatar a sus conciudadanos de la ignorancia. En palabras de Iván Jaksic, Letelier

\begin{abstract}
Apuntó que las verdades teológicas habían fallado en su intento por atraer a todos los hombres y que, además, habían introducido conflictos irresolubles en la sociedad. La metafísica, el segundo estado en el esquema de Comte, era igualmente falible para la realidad chilena, en la forma en que la aplicaba Letelier. [...] Sólo la ciencia, sugirió, podía traer la tan necesaria unidad para la sociedad y proveer la base para el progreso ordenado de la humanidad ${ }^{33}$.
\end{abstract}

A tal punto llegó el convencimiento de Letelier de que el trabajo de Comte podía ser transferible a la realidad del país, que, en 1889, presentó un detallado informe al gobierno de José Manuel Balmaceda, en el que señalaba cuáles eran, para él, las reformas que necesitaba la enseñanza. Su propuesta, denominada "sistema concéntrico”, tenía por “objeto reemplazar el anterior sistema de estudiar asignaturas completas y sucesivas por el de agrupar los ramos que pertenecían a un mismo orden de conocimiento, de manera que su estudio empezara en el primer año y continuara en un desarrollo progresivo hasta el sexto"34. O, en otras palabras, que la enseñanza siguiera un proceso de aprendizaje ascendente, yendo de las ciencias más "simples” hasta las ciencias más “complejas”35.

\title{
${ }^{32}$ Véase ibídem, p. 53.
}

${ }^{33}$ Ibídem, pp. 54-55. El original en inglés dice: "He [Letelier] pointed out that theological truths had failed to appeal to all men and, in addition, that they introduced conflicts of an unresolvable nature in society. Metaphysics, the second stage in Comte's scheme, was equally fallible in Letelier's application to Chile. [...] Only science, he suggested, could bring about much-needed unity to society and provide the basis for the orderly progress of humanity".

${ }^{34}$ Campos Harriet, Fernando: Desarrollo Educacional..., 1960, p. 84.

${ }^{35}$ Véase Jaksic, Iván: Academic Rebels in Chile..., 1989, p. 55. 
El método concéntrico sugerido por Letelier se ensayó en el Liceo de Chile, y ya para 1893 se hizo extensivo al resto de los colegios secundarios del Estado. Su plan de estudios, de seis años, era el siguiente: Castellano y Matemáticas eran ramos fundamentales, y Francés e Inglés (o Alemán) se estudiaban paralelamente durante esos seis años; la Zoología y la Botánica, de primero a cuarto año; Higiene, Biología, Química y Física, en quinto y sexto año; el Canto, la Gimnasia y el Dibujo, de primero a sexto año; la Filosofía tenía una cátedra y la religión se enseñaba dos veces a la semana, de primero a cuarto año ${ }^{36}$. Todo esto, según Letelier, levantaría

gradualmente el edificio del saber, creando en el primer año una base de conocimientos que se ensancha y desarrolla en los siguientes. El educando así no va estudiando ciencias nuevas á medida que va adelantando en su carrera, sino que va desarrollando sus conocimientos en aquellas ciencias en que se inició al principio del curso ${ }^{37}$.

Como era de esperarse, los católicos consideraron que el sistema concéntrico atentaba contra el estudio de la religión, poniendo nuevamente en el tapete la discusión sobre la relación Iglesia-Estado y el consecuente proceso de secularización. La contraofensiva de los católicos estuvo encabezada por La Revista Católica (RC), órgano oficial del arzobispado y vocero oficioso del Partido Conservador, y apoyada constantemente por los profesores y estudiantes de la Universidad Católica de Chile, fundada en 1888.

El 18 de agosto de 1894, la $R C$ dedicó un extenso espacio a analizar los alcances del nuevo plan. El artículo comenzaba diciendo que los pedagogos modernos (como Letelier) estaban equivocados al pensar que "la verdadera doctrina sobre la clasificación y dependencia de las ciencias" había sido un invento de los últimos años, y que, por tanto, afirmar que la Iglesia no apoyaba el trabajo científico era una falacia. Según el autor,

Los antiguos filósofos investigaron con admirable sagacidad la comunidad de principios que algunas ciencias tienen entre sí y el auxilio que se prestan mutuamente. [...] La escolástica continuó esta obra y tomando la palabra ciencia en su verdadera acepción, esto es, en cuanto designa el conjunto de verdades obtenidas por medio de la demostración, examinó la conexión de los principios, las distintas series de objetos á

${ }^{36}$ Véase Campos Harriet, Fernando: Desarrollo Educacional..., 1960, p. 85.

${ }^{37}$ Citado por La Revista Católica (RC), número 1387, Santiago, 18 de agosto de 1894, p. 42. 
que se aplican, el diverso modo como pueden considerarse estos mismos objetos, y después de abarcar la ciencia entera, la dividió en cinco [sic] grupos, que comprendían la física ó ciencias naturales, las matemáticas, la lógica metafísica, la lógica moral. [...]

Sin embargo, y a pesar del importante papel que los católicos asignaban a la escolástica, Letelier la había dejado de lado en su esquema. La $R C$ continuaba:

El positivismo moderno [...] reclama para sí la gloria de haber él descubierto la verdadera clasificación de las ciencias. [...] Basta exponer el sistema de Compte [sic] para estimarlo en lo que vale. La esfera de los conocimientos humanos comprende, según este filósofo, sólo seis órdenes de ciencias fundamentales: las matemáticas, la astronomía, la física, la química, la biología y la sociología. La teología, la moral, la lógica y la metafísica, quedan relegadas en este sistema á la categoría de aquellos poéticos ensueños que por tantos siglos acarició la humanidad. [...] Desgraciadamente, en los métodos concéntri$\cos [\ldots]$ ha sido definitivamente desterrada la enseñanza de las lenguas sabias y de la filosofía, reemplazándose ésta por una estéril metodología positiva que ni da leyes al raciocinio, ni analiza los criterios, ni se extiende más allá del orden puramente sensible. La enseñanza de la historia sagrada, del catecismo y de los Fundamentos de la Fe, está condenada también á la misma suerte; y aunque todavía queda en los colegios del Estado un simulacro de aquellos estudios, ya las pruebas finales de esos ramos han sido suprimidas como inútiles; maña hipócrita á la vez que certera de que se valen para extirparlos cautelosamente ${ }^{38}$.

Con este tipo de ofensivas, la $R C$ pretendía que la comunidad cristiana se resistiera a la enseñanza de las nuevas doctrinas, y que hiciera lo posible por educar a sus hijos en los colegios que garantizaran la enseñanza de la filosofía escolástica, de la Historia Sagrada y del Catecismo. De ese modo, creía, se podrían enfrentar las amenazas provenientes del Estado docente y afianzar el poder de los particulares católicos.

La posición de la Iglesia se mantuvo durante los años siguientes. En 1902, los agentes estatales llevaron a cabo un importante "Congreso de Enseñanza Pública”, en el cual, entre otras cosas, se resolvió que la educa-

${ }^{38} R C$, número 1387, Santiago, 18 de agosto de 1894, pp. 42-45. Las cursivas son nuestras. 
ción espiritual de los colegios fiscales no debía "tener por base religión alguna", y que, por el contrario, debía fomentarse "la moral independiente"39. La respuesta de los católicos la dio el propio arzobispo Mariano Casanova, a través de su "Pastoral sobre la necesidad de la enseñanza religiosa en las escuelas y colegios públicos”, que fue publicada íntegramente por la $R C$.

El arzobispo comenzó utilizando un argumento constitucional para defender la postura de la Iglesia. Según él, la religión católica era "la de la nación chilena, la única que reconoce, manda profesar, proteger y amparar nuestra Carta Fundamental”40. Los colegios estatales debían contar con una apropiada enseñanza espiritual, a riesgo de caer en la "tiranía" de la irreligión:

La educación religiosa es todavía más necesaria en las sociedades democráticas y republicanas, que en las que se rigen por otros sistemas de gobierno. Hija del cristianismo, la democracia moderna es uno de los más grandes progresos sociales y una de las más hermosas conquistas del Evangelio. Pero hay mil escollos en que puede estrellarse; existen pendientes que pueden serle funestas y la amenazan numerosos peligros, cuyo único contrapeso es la Religión. El despotismo puede prescindir de la fe, la libertad nó [sic]. Un pueblo sin religión llegará a ser esclavo de ominosa tiranía, y si no quiere servir, debe creer, porque la libertad sólo puede ser engendrada por la verdad ${ }^{41}$.

También bajo esta concepción democrática de la sociedad cristiana, Casanova recalcó que los católicos apoyaban el progreso a través de la ciencia, pues "la verdadera ciencia no reniega de Dios, porque Él es el Señor de las ciencias, el centro de toda subsistencia; la razón de todo conocimiento, la regla de toda buena vida"42. Por todo esto, al concluir la Pastoral ordenaba "á los párrocos que cumplan con el deber de dirigir y vigilar la enseñanza religiosa en las escuelas públicas de sus respectivas parroquias; que exijan el respeto debido al derecho que la ley les otorga", sin vacilar en reclamar "ante la autoridad correspondiente, toda vez que su derecho les sea desconocido ó la ley violada" 43 . El objetivo de que la religión no "quedara entregada en manos de sectarios” era más fuerte que las

\footnotetext{
${ }^{39} R C$, número 36, Santiago, 17 de enero de 1903, pp. 709-710.

40 Ibídem, p. 706.

${ }^{41}$ Ibídem, pp. 707-708.

${ }^{42}$ Ibídem, pp. 711-712. Las cursivas son del original.

${ }^{43}$ Ibídem, p. 713.
} 
"sacrílegas burlas" que pudieran realizarse en los establecimientos fiscales a costa del catolicismo ${ }^{44}$.

Así, tenemos que, durante esta época, la argumentación de los católicos corrió por dos carriles paralelos —uno "constitucional” y otro "científico”-, y que su empleo dependía de las circunstancias. En una ocasión, por ejemplo, la $R C$ embistió en contra del ministro de Instrucción Pública por negarse a dar cabida a la "Ética y á la Teodicea" en el nuevo plan de estudios, recalcando que "si la Religion del Estado es la Católica, asegurada y protegida por la Constitución; si esos consejeros [de Instrucción Pública] no son otra cosa que empleados á sueldo de un gobierno católico, pagados con el dinero de los católicos y para servir á los católicos, ¿qué cinismo de desverguenza los ciega hasta el punto de desterrar á Dios de la enseñanza del Estado?”45.

En otra oportunidad, y a propósito de que el ministro Guillermo Rivera insistiera en manifestarse contrario a que los colegios católicos recibieran ayuda estatal por impartir una enseñanza "sectaria" y carente de "base científica”, el mismo periódico dedicó nueve páginas de su edición del 4 de febrero de 1905 a explicar de qué forma la Iglesia apoyaba el trabajo científico. En palabras de la $R C$, decir que los católicos aborrecían la ciencia porque ésta se oponía a la fe, era señal del desconocimiento profundo que tenían de la ciencia aquellos que se dedicaban día a día a criticar a la religión:

El Sr. Ministro no tiene de representante de las Ciencias más que el título de Ministro de Instrucción; el Sr. Ministro no ha estudiado esa Religión que mira con tanto desdén, y los que la han estudiado abrazan con tanto amor; el Sr. Ministro no figura, al menos que yo sepa, ni siquiera ad honorem entre los miembros de Academias científicas ó Universidades. Y, sin embargo, el Sr. Ministro hace afirmaciones tan solemnes con esa base científica ${ }^{46}$.

A continuación expresaba por qué, a su juicio, el raciocinio del ministro era insustancial, al mismo tiempo que muy poco "liberal”:

¿Qué entiende el Sr. Ministro cuando dice que la Religión no tiene base científica? No puede ser sino una de estas dos cosas: ó que no tiene fundamento racional; ó que no tiene

\footnotetext{
${ }^{44}$ Ibídem, p. 714.

${ }^{45} R C$, número 74, Santiago, 20 de agosto de 1904, p. 121.

${ }^{46} R C$, número 85 , Santiago, 4 de febrero de 1905 , p. 3. Las cursivas son del
} original. 
fundamento experimental como la Física ó la Química, por ejemplo. Si esto último fué lo que quiso decir, no hizo un descubrimiento: las enseñanzas religiosas no se miden, no se pesan, no están al alcance del microscopio ó telescopio, ni de ningún aparato de ciencias experimentales; pero, si ésa era razón para negar los auxilios del Estado á los colegios que enseñan religión, para ser lógico, debió negarlos también á los demás colegios donde se enseñan la Geografía, las Historias, las leyes, etc., ya que tampoco tienen base experimental. [...] ¿Le parece al Sr. Ministro muy conforme con la libertad de pensar que profesa, el valerse de la autoridad para imponer, en cuanto le es posible, sus propias opiniones y cerrar el paso á las ajenas, aun cuando sea perjudicando á una gran cantidad de niños, que tal vez se queden sin instruirse convenientemente gracias á la actitud del Sr. Ministro? ${ }^{47}$

Las consecuencias de esta contraofensiva no se hicieron esperar: pocos días después, el ministro Rivera renunció a su cargo, seguramente angustiado al ver que sus discrepancias dogmáticas con la Iglesia habían llegado a un punto insostenible ${ }^{48}$.

Para mediados de 1906, las disputas estaban concentradas únicamente en el tipo de educación religiosa impartida por el Estado en los liceos públicos, pues era ahí donde el sistema concéntrico había ganado más adeptos. El interés de la Iglesia por la juventud que asistía a estos colegios quedó de manifiesto en una nueva "Crónica" de la $R C$, en la que el autor, inspirándose en la Facultad de Humanidades de la UCH, solicitaba que el Consejo de Instrucción Pública declarara que el ramo de Religión tuviera "la misma categoría que los demás ramos en lo que se refiere a los exámenes anuales”49, dejando ver que si el resto del currículo tenía examinación obligatoria, no había razón para que el estudio del catolicismo no la tuviera.

La aquiescencia de este autor de la $R C$ a aceptar que el Estado examinara el ramo de religión no era una mera divagación intelectual. Por el contrario, respondía a una estrategia para conseguir que los sostenedores del "cientificismo" no descalificaran a los católicos de buenas a primeras. Es cierto que no todos los fieles adherían a esta postura, pero el temor a que los jóvenes perdieran la fe de sus padres llevó a que, con el paso de los

${ }^{47}$ Ibídem, pp. 3-8. Las cursivas son del original.

${ }^{48}$ Véase $R C$, número 86, Santiago, 18 de febrero de 1905, pp. 152-153. La $R C$ celebró la renuncia de Rivera con el siguiente "epitafio”: “Aquí yace Don Guillermo,/ Ministro de destrucción/ Y de pública injusticia./ No murió, nó, por enfermo:/ Lo mató aquel Syvetón/ Que lo apellidó inmundicia”.

${ }^{49} R C$, número 122, Santiago, 18 de agosto de 1906, p. 151. 
años, algunos miembros del clero se allanaran a que los agentes estatales intervinieran a fin de año en la examinación de la religión. Al parecer, esa era la única forma de conseguir que los enemigos de la Iglesia aceptaran que la "fe no sólo no es adversaria ni antagonista de la razón, sino su mejor aliada"50.

Esta forma de ver la relación Iglesia-Estado en materia curricular, cercana a una suerte de transacción, fue más beneficiosa que la representada por el ultramontanismo recalcitrante. En efecto, en 1912 los asistentes al “Congreso Nacional de Enseñanza Secundaria”, que incluía representantes del Estado ${ }^{51}$, decidieron que la "moral independiente" no debía continuar prevaleciendo en los colegios secundarios, y que había de proclamarse nuevamente la "verdadera doctrina ética o moral" del catolicismo ${ }^{52}$. Esto, sin duda, significó un avance para las aspiraciones de los católicos que apoyaban una posición más cercana al Estado.

Entre éstos, habría que destacar dos casos aparecidos en la $R C$. En primer lugar, al Vicariato Apostólico de Tarapacá, que, en una Pastoral publicada por la $R C$ el 17 de mayo de 1913, declaró que era una injusticia sostener que la Iglesia era "enemiga de la instrucción del Estado, simple y llanamente por ser del Estado" 53 , y que eso sólo podía creerlo quien ignorara "el mutuo favor que en todo tiempo se han prestado la Iglesia y el Estado en el campo de la instrucción” nacional ${ }^{54}$.

El segundo caso es un artículo de diciembre de ese año, cuya intención era demostrar que la Iglesia siempre había ayudado al Estado, incluso en los momentos más conflictivos. El mejor ejemplo de esa ayuda, señalaba, habían sido los más de 300 profesionales que se habían graduado hasta 1913 en la Universidad Católica, pues era señal de "la inmensa valía del auxilio que [ella] presta gratuitamente al Estado en la grande obra de la educación nacional y la enorme economía que esta admirable Institución docente significa para el mismo Estado" 55 .

Es decir, en esta época ciertos católicos comenzaron a apreciar que la Iglesia construyera una relación más armónica con los gobiernos civiles, por lo menos en lo que se refiere al sistema concéntrico. Esto no quiere decir que los conflictos entre ambos grupos hubieran cesado, pero sin duda

\footnotetext{
${ }^{50}$ Ibídem, p. 150.

${ }^{52} R C$, número 269, Santiago, 19 de octubre de 1912, p. 751.

${ }^{53} R C$, número 283, Santiago, 17 de mayo de 1913, p. 870.

${ }^{54}$ Ibídem.

${ }^{55} R C$, número 297, Santiago, 20 de diciembre de 1913, p. 973.
}

${ }^{51}$ Sobre este Congreso, véase Baeza, Andrés: "La Dimensión Educacional de la Crisis del Centenario en Chile. Modernización, Nacionalismo y Reforma”, 2006, capítulo V. 
el debate curricular fue perdiendo cada vez más fuerza, tanto por el paso del tiempo como por la actitud menos reticente de algunos católicos a aceptarlo.

Ahora bien, si dentro de los sectores más influyentes de la Iglesia había diferentes posiciones frente al tema curricular, ¿qué sucedía con el resto de los sostenedores de la educación particular, fueran éstos católicos o no? ¿Qué opinaban, por ejemplo, los misioneros y los colegios secundarios femeninos del Estado docente? ¿Qué pensaban de una eventual complementación entre el Estado y los privados?

Intentaremos contestar estas preguntas en el apartado que sigue. No obstante, digamos desde luego que, a nuestro entender, las argumentaciones "económicas" y de complementación que algunos católicos esgrimían en los casos que describimos más arriba, no fueron en absoluto una novedad, pues históricamente el Estado y muchos establecimientos particulares habían tenido una aceptable relación recíproca, tanto en materia académica como en el plano financiero. En este último, la solicitud de subvenciones, por un lado, y la entrega de las mismas, por el otro, fueron mecanismos efectivos para reforzar dicha cooperación.

\section{3. ¿Quiénes solicitan la subvención del Estado?}

(1890-1910)

Señor Ministro [de Instrucción Pública]:

Una cantidad de jóvenes señoritas han recibido en mi establecimiento una esmerada i prolija educacion de la que me enorgullezco i que me alienta a seguir con teson en la tarea que voluntariamente nos hemos impuesto yo i mis hijas. Empero la situacion por que atraviesa el pais, los costos que es hoi el monto de los colejios, $i$ tomando en consideracion que V.S. ha sido i es protector decidido de la educacion de la mujer base de la sociedad, me acojo a

Vuestra benevolencia para que despues de haber tomado las informaciones o datos que creyere oportuno nos conceda el Supremo Gobierno una subvencion en la forma en que ha sido otorgada a varios otros establecimientos de ésta clase. Catalina Orengo, Directora del Liceo Europeo de Señoritas de Santiago (Ministerio de Instrucción Pública, volumen 870).

El proceso de subvenciones estatales se dio paralelamente al conflicto curricular. Sin embargo, a diferencia de éste, la cuestión de las subven- 
ciones no generó mayores desencuentros ideológicos, lo que permitió que un amplio sector de particulares se relacionara relativamente bien con los agentes estatales. Así ocurría con la mayoría de los establecimientos privados, que para los efectos de este trabajo hemos clasificado en misiones religiosas en la Araucanía, colegios regionales y liceos secundarios femeninos de Santiago ${ }^{56}$. A pesar de que representaban mundos y objetivos distintos, todos ellos compartían la misma aspiración: lograr que los políticos asignaran una parte del presupuesto nacional a sus respectivas instituciones.

\subsection{Misiones religiosas en la Araucanía}

Durante la época colonial, el trabajo misionero en la Araucanía fue considerado como un difusor de las ideas provenientes de la capital, tanto en su labor evangelizadora como en su potencial utilización política. Para fines del siglo XIX (sobre todo luego de que la “pacificación” de la Araucanía, emprendida a principios de la década de 1880, dejara las puertas abiertas para que los chilenos no indígenas asumieran el control absoluto de la región), aquella orientación no había variado demasiado, y los gobiernos centrales continuaban considerando a las misiones como un vehículo de primer orden para expandir la “civilización” entre los indígenas del sur del país ${ }^{57}$.

La principal preocupación de los misioneros era conseguir que sus evangelizados se reunieran en comunidades cristianas, esto es, comunidades donde se respetaran la monogamia y los demás mandamientos católicos. Una de las formas de alcanzar dicha aspiración era creando escuelas misionales, las cuales cumplían una doble función: aglutinar y ejemplificar. Los religiosos eran conscientes de que esta forma de acercarse al indígena era aceptada por los agentes estatales, entre otras razones, porque en aquellas zonas, alejadas de la ciudad y de muy difícil acceso, sus aulas constituían los únicos espacios donde se daban a conocer las normas establecidas por el Estado nacional. Por esta razón, no es de extrañar que los misioneros tuvieran la suficiente confianza para solicitar la ayuda financiera estatal, y que su principal estrategia fuera explicitar la mutua colabora-

${ }^{56}$ Por razones de espacio, hemos dejado de lado otros tipos de establecimientos particulares subvencionados, como es el caso de las escuelas regentadas por instituciones de beneficencia auxiliadas por el Estado.

${ }^{57}$ Véase Serrano, Sol: "De Escuelas Indígenas sin Pueblos a Pueblos sin Escuelas Indígenas: La Educación en la Araucanía en el Siglo XIX”, 1995-1996, pp. 423-474. 
ción que podían prestarse ambos sectores, en el entendido de que sus misiones fueran apreciadas por el gobierno.

Entre 1890 y 1910, las principales órdenes religiosas en la Araucanía eran los capuchinos, los franciscanos y los escolapios ${ }^{58}$. A éstos se les unían algunas órdenes de monjas, cuyo trabajo era tan importante como el de sus pares masculinos. Las necesidades de estas congregaciones dependían de las circunstancias y del contexto en que viviera cada una, aunque la mayoría requería un auxilio monetario más o menos estable por parte del Estado $^{59}$. De ahí que las peticiones de subvenciones fueran anuales, como también que en éstas, sin importar quién fuera el destinatario o la misión que las formulara, los argumentos para recibir la ayuda se repitieran.

Los misioneros iniciaban sus solicitudes destacando que las comunidades indígenas podían beneficiarse notablemente con las escuelas que funcionaban a su cargo. Esta posición la encontramos, por ejemplo, en una nota dirigida el 20 de febrero de 1895 por el capuchino José de Potries al Inspector General de Instrucción Primaria, Abelardo Núñez. Según Potries, durante los años que había estado a cargo de la misión establecida en Bajo Imperial, había podido imponerse "de la convivencia y ventajas que se obtendrían en suministrar alguna educacion á los indíjenas que en tanto número se encuentran en esta localidad”60. En su pensar, la única

medida civilizadora que podria emplearse en favor de estos desgraciados, seria la fundacion de escuelas, en las que se les suministraria una enseñanza que en poco tiempo pudiera sacarlos del estado de ignorancia, que hoi solo los hace aptos para la ociosidad i el pillaje, desconociendo en absoluto sus obligaciones con respecto á Dios, á su madre patria y a sus semejantes ${ }^{61}$.

A sabiendas de que el Estado y sus delegados, como era el caso de Núñez, compartían este diagnóstico, los capuchinos de la localidad habían decidido construir seis escuelas en Bajo Imperial y sus zonas aledañas, esperando que la enseñanza por ellas impartida fuera de alguna forma subsidiada por el dinero fiscal. Dice:

${ }^{58}$ Más al sur, se ubicaban los salesianos, quienes concentraban sus fuerzas en desarrollar la educación de una pobre y alejada Punta Arenas. Véase Archivo Nacional de Chile, Ministerio de Instrucción Pública (A.N.M.I.P.), volumen 725.

${ }^{59}$ Como bien dice Sol Serrano, "para los misioneros, las limitaciones en la educación indígena estaban en la oferta y no en la demanda. Faltaban recursos", en Serrano, Sol: “De Escuelas Indígenas...”, 1995-1996, p. 471.

${ }^{60}$ A.N.M.I.P., volumen 1079 , sin fojas exactas.

${ }^{61}$ Ibídem. 
Para dar principio á esta obra rejenadora me he propuesto crear seis escuelas mixtas y destinarlas á dar educacion gratuita á los niños indíjenas de ambos sexos, [...] i como mis recursos no alcanzarian para pagar el sueldo á los maestros, gastos de libros i otros útiles, rogaría encarecidamente á V.S. [Núñez] se sirviera arbitrar los medios necesarios para que el Supremo Gobierno subvencionara con \$50 [pesos] mensuales cada una de las escuelas. [...] Las escuelas quedarian en todo sometidas á los reglamentos que rijen las fundadas por el Estado $^{62}$.

La argumentación de Potries contiene diferentes claves, que ayudan a comprender la aspiración de estos educadores particulares. En primer lugar, establece que los mapuches no tenían un fácil acceso a la educación, y que se debía hacer un esfuerzo considerable si se pretendía que ellos se convirtieran en verdaderos ciudadanos chilenos, es decir, ciudadanos que respetaran a Dios y “á su madre patria”. El trabajo misionero, en palabras de Potries, era un medio práctico para difundir el espíritu nacional entre los indígenas, aunque siempre con auxilio estatal. Esta complementación entre ambos sectores permitiría vencer los obstáculos derivados de la falta de recursos, y que el objetivo final pudiera efectivamente conseguirse.

Ahora bien, es evidente que Potries estaba abierto a que el Estado fuera quien manejara los hilos de esta mutua cooperación, y, que, por lo tanto, la relación entre ambos sectores no fuera completamente horizontal. En efecto, que el misionero aceptara que las escuelas capuchinas quedaran sometidas a los reglamentos que regían a los establecimientos públicos, era una demostración de las necesidades económicas de los misioneros de la Araucanía, como también de que el instinto de sobrevivencia de los misioneros era más fuerte que las orientaciones que impartía el arzobispado de Santiago con respecto a las cuestiones curriculares ${ }^{63}$.

Los franciscanos, por su parte, mantenían una posición similar a la de los capuchinos. Los hijos de San Francisco regentaban diversas escuelas en el sur del país, cada una de las cuales soportaba necesidades y problemas específicos. Sin embargo, todas ellas compartían la forma de solicitar las subvenciones. Así lo hacía, por ejemplo, en la ciudad de Castro, una de las más alejadas del centro administrativo de Chile, una escuela que, en 1897, educaba a 117 alumnos, quienes aprendían, entre otros ramos, Lectura, Caligrafía, Historia Sagrada, Historia de Chile, Geografía, Aritmética y Sistema Métrico.

\footnotetext{
62 Ibídem.

${ }^{63}$ Véase supra, pp. 38-42.
} 
Este colegio había sido sostenido durante cuarenta años “con las limosnas que los fieles dan al Convento, ó que podemos adquirir con el trabajo propio de nuestro ministerio, como Misioneros”64. No obstante, en el último tiempo se habían visto obligados a solicitar la ayuda del Estado, la cual, a esas alturas, era imperiosa:

Si el Supremo Gobierno, no ayuda al sostenimiento de éste plantél de educación [...] decaerá notablemente, no pudiendo nosotros, por la escases de nuestros recursos, mantenerlo en el estado en que se halla; contribuyendo en consecuencia [...] [al] detrimento notable de la enseñanza de la juventud estu$\operatorname{diosa}^{65}$.

En Nacimiento, en tanto, encontramos el mismo diagnóstico, siempre por parte de los franciscanos. En marzo de 1900, Luis Sepúlveda, superior de la Misión de dicho departamento, informaba que la escuela de hombres dirigida por la orden estaba pasando penurias, y que los 25 pesos mensuales que el gobierno le había asignado durante los años anteriores eran “a todas luces insuficiente[s] para el sostenimiento de la escuela porque con ella no se alcanza a pagar ni el maestro que debe dirijirle"66. Con palabras que perfectamente podrían ser enarboladas en el siglo XXI, Sepúlveda dejaba entrever que la calidad de la educación dependía de los incentivos salariales a los profesores, pues "siendo la asistencia media de cuarenta alumnos no se encuentra una persona medianamente competente que quiera, por tan mísero sueldo, contraer su atención i consagrar sus fuerzas [a] un empleo tan mal remunerado"67.

Esta forma de ver el problema educacional demuestra que los misioneros tenían una visión bastante "moderna” de la enseñanza nacional. Lo anterior lo confirma una carta enviada en septiembre de 1900 por Leandro Cuixart, rector de los padres escolapios de Concepción, al ministerio de Instrucción Pública, en la que manifiesta que la posible clausura de los establecimientos misionales por falta de recursos podría significar un gasto extraordinario al Estado, en el sentido de que éste se vería obligado a satisfacer toda la demanda estudiantil por sí solo. Dice:

Desde hace tres años la Comunidad Escolapia sostiene en Concepción, además de un colegio de instrucción secundaria con internado, medio pupilaje y externado, dos escuelas de

\footnotetext{
${ }^{64}$ A.N.M.I.P., volumen 1259, f. 141.

${ }^{65}$ Ibid., f. 141.

${ }^{66}$ A.N.M.I.P., volumen 1355, sin fojas exactas.

${ }^{67}$ Ibídem.
} 
enseñanza, primaria la una y superior la otra, siendo ambas para niños pobres. En estas escuelas el aprendizaje es gratuito y en ellas por añadidura se proporcionan gratis á los alumnos los libros y todo el material de enseñanza. La asistencia media de estudiantes llega por ahora al número de ciento cuarenta por día. Compromisos pecuniarios contraidos desde tiempo atrás para construir el vasto y adecuado edificio de nuestro colegio, nos obligan á recargar enormemente las tareas escolares en un reducido personal propio, para conseguir hacer puntualmente el servicio de aquella deuda, no distrayendo fondos en pago de auxiliares extraños á nuestro instituto. [...] Cree el infrascrito que la clausura ó la reducción de esas dos escuelas, que coadyuvan á la acción gubernativa de difundir la instrucción en el pueblo, ha de ser estimado por U.S. como un mal, que conviene precaver pues impondría al Estado la necesidad de crear y sostener á su costo otra escuela fiscal que llenara ese vacío. En consecuencia, me permito solicitar de U.S. se digne auxiliar la obra de nuestras escuelas gratuitas para niños pobres, con una módica subvención fiscal de dos cientos pesos mensuales, cantidad que apenas representa el cánon de arrendamiento de local que el Fisco gasta aquí en algunas escuelas, y que á nuestra Comunidad permitirá proseguir la enseñanza que damos á los menesterosos, teniendo siquiera en medio de nuestra abrumadora tarea el consuelo de que tantos desvalidos no se encontrarán expuestos á quedar privados de la enseñanza que solicitan, porque sus maestros carecemos de recursos para atenderlos ${ }^{68}$.

El argumento de Cuixart se asemeja al de los capuchinos y franciscanos, aunque su visión es más pragmática que la de ellos, ya que entiende la colaboración entre el Estado y los misioneros desde una perspectiva principalmente económica ${ }^{69}$.

Finalmente, digamos algo sobre las hermanas terciarias franciscanas, una de las órdenes femeninas más importantes de aquella época, y cuya

${ }^{68}$ A.N.M.I.P., volumen 1409, sin fojas exactas.

${ }^{69}$ Este razonamiento es similar al que empleó la $R C$ en 1913 , cuando señaló que el Estado ahorraba grandes sumas de dinero gracias a la educación impartida por la Universidad Católica. Véase supra, pp. 43-44. Según Cuixart, incluso los métodos de enseñanza debían ser puestos en práctica bajo una consigna económica, ya que una buena implementación de ellos podía conllevar réditos positivos para los particulares y el Estado. De ese modo, en 1895 en su calidad de rector del Colegio Seminario de Copiapó, Cuixart señalaba lo siguiente: "Sin perjuicio del sistema concéntrico de enseñanza implantado en dicho Establecimiento, para el curso de humanidades, me propongo establecer con mas desarrollo la sección de Comercio y ramos de Minería, que son estudios necesarios y adaptables á la índole de esta provincia”, en A.N.M.I.P., volumen 1069, f. 21. 
labor se concentraba en el colegio de niñas indígenas de Angol. La pobreza de este establecimiento y la consecuente necesidad de contar con el auxilio estatal, las llevó, en julio de 1894, a solicitar la intercesión del intendente de Malleco con el fin de lograr que el Ejecutivo les asignara una subvención para completar la construcción de sus instalaciones. A raíz de esta nota, el intendente visitó el colegio, haciéndose una idea del edificio y de los materiales con que contaban las monjas. Luego de recorrer el recinto y ver que el “edificio se hace completamente estrecho”, se dirigió al ministerio, indicando que el "Supremo Gobierno haria un gran servicio a la instrucción pública y a la civilización de los indíjenas del sur”, concediendo la cantidad de tres mil pesos a las franciscanas ${ }^{70}$.

La intercesión del intendente dio resultados más o menos inmediatos. El ministro solicitó que Abelardo Núñez enviara a un visitador de escuelas primarias a Angol para que informara sobre los beneficios que podría traer para las niñas indígenas la subvención. El informe de J. Contreras Varas, redactado el 6 de agosto de 1894, fue corto pero preciso:

La enseñanza que suministra el Colejio de niñas indíjenas que en esta ciudad rejentan las Hermanas Terciarias Franciscanas, es la misma y de los mismos ramos que se cursan en las escuelas públicas que sostiene el Estado, debiendo agregarse á éstos el Francés y la Historia Eclesiástica. Hay en él á la fecha 83 alumnas matriculadas: de ellas 40 son internas y 34 esternas. El edificio en que funciona es tal cual lo pinta el Sr. Intendente [de Malleco] en la nota que antecede, por lo que soy de parecer que el Supremo Gobierno haria un gran servicio á la instrucción concediendo á dicha Orden la suma de pesos [3.000] que se solicita para llevar á cabo la construcción de la casa que al presente edifica con el objeto de dar mas comodidad al establecimiento ${ }^{71}$.

El 14 de marzo del año siguiente, el gobierno aceptó ayudar a la escuela de las hermanas terciarias. Es cierto que el monto final fue menor al solicitado; sin embargo, el objetivo final se había conseguido, gracias a lo cual la escuela podía respirar tranquila, por lo menos hasta que fuera necesario pedir otra subvención.

Este requerimiento de las monjas terciarias demuestra que en el sistema de solicitudes participaban diversos actores, cuestión que podía retardar la tramitación, aunque también beneficiarla. En el caso específico que hemos citado, no cabe duda que la intercesión del intendente y la del visitador de

\footnotetext{
${ }^{70}$ A.N.M.I.P., volumen 1079, sin foja exacta.

${ }^{71}$ Ibídem, sin foja exacta.
} 
escuelas primarias ante el ministerio de Instrucción Pública, favoreció a las franciscanas, confirmando, a su vez, que los agentes estatales se preocupaban de conocer a ciencia cierta en qué se gastaba el dinero de las subvenciones.

Como veremos en el apartado número 4, el número total de subvenciones fue aumentando a lo largo de los años, y los misioneros del sur no fueron la excepción a esta regla. Esto se explica porque durante las primeras décadas del siglo XX, "la escuela misional siguió siendo la única instancia educativa orientada específicamente hacia el pueblo mapuche"72. En ese sentido, el apoyo financiero estatal fue una suerte de reconocimiento para los religiosos, quienes parecían ser los únicos dispuestos a sacrificar su vida en pro de los indígenas. Lo anterior, por cierto, no quiere decir que el dinero fuera en beneficio directo de los misioneros, sino más bien de una obra que, tanto el Estado como otros personeros, consideraban indispensable ${ }^{73}$.

\subsection{Colegios regionales}

Al mismo tiempo que los misioneros enseñaban en la Araucanía, otro tipo de establecimientos particulares cobraba fuerza en los lugares alejados de la capital: los colegios regionales regentados por educadores laicos. Aunque estos establecimientos se ubicaban a lo largo y ancho del territorio, a fines del siglo XIX y principios del XX la mayoría de ellos se concentraba en el sur del país, cuestión que nos llevó a enfocar nuestra atención en las solicitudes de subvenciones provenientes de esa zona.

De las muchas solicitudes regionales depositadas en los archivos del Ministerio de Educación, dos grupos de demandantes llamaron nuestra atención, tanto por su cantidad como por la riqueza de la información que proveen sobre sus instituciones y los métodos de enseñanza utilizados. Nos referimos, por un lado, a los distintos colegios alemanes de Los Ángeles, Temuco, Valdivia y Osorno, y, por otro, a ciertas instituciones situadas en Concepción y sus alrededores, cuyas estrategias se inspiraban en fenómenos políticos y en argumentos que hoy llamaríamos "regionalistas".

Los colegios alemanes del sur

Sabido es que el aporte de los alemanes en la colonización del sur de Chile se transformó en una suerte de icono de la “civilización”, desde que

${ }^{72}$ Serrano, Sol: “De Escuelas Indígenas...”, 1995-1996, p. 472.

${ }^{73}$ Véase, por ejemplo, $R C$, número 94, Santiago, 17 de junio de 1905, pp. 737741. 
Manuel Bulnes, mediante la intervención de Vicente Pérez Rosales, firmara a fines de la década de 1840 un acuerdo para recibir el primer contingente de extranjeros ${ }^{74}$. A pesar de que algunos periódicos católicos vieron con malos ojos que aquella zona se convirtiera en un "foco de la propaganda protestante" 75 , la mayoría de los políticos creyó que la inmigración traería más progreso "que los mejores libros, más riquezas que mil naves cargadas de manufacturas"76. De ahí que el apoyo a los colonos fuera prácticamente unánime, sobre todo en materias — como la educación — donde su conocimiento podía ser un aporte significativo para el avance de la sociedad chilena.

Fue así como el Ejecutivo comenzó a apoyar a las escuelas regentadas por alemanes, práctica que, a partir de la década de 1890, se haría bastante habitual. Sin embargo, antes de que esta ayuda se institucionalizara, los colonos debieron sobreponerse a todo tipo de dificultades y penurias. Según Karl Anwandter, patriarca de la colonización valdiviana, sus coterráneos hacían ingentes sacrificios en pos de la educación de la región, pero muchas veces los gobiernos no tomaban en cuenta aquel esfuerzo. En una carta a su amigo Benjamín Vicuña Mackenna, fechada en 1867, Anwandter se quejaba de que:

El estado tan poco satisfactorio de las escuelas públicas de aquí nos obligó a nosotros, los alemanes, a fundar en todas partes i conservar hasta el presente, escuelas propias con grandes sacrificios de dinero. La primera fundación de la escuela alemana de Valdivia importó \$600.-, más tarde la fabrica del edificio \$350.- i la conservación de la escuela demanda \$174.- mensualmente. Esta es una carga mui pesada para los alemanes de aquí, que sobrepuja mucho los impuestos directos de que pudiéramos ser recargados. Para la fundación de la escuela i construcción del edificio, el Gobierno no nos ha prestado ausilio alguno; para los gastos de sostenimiento contribuye desde un año con \$25.- mensuales; pero en las 4 clases de nuestra escuela reciben actualmente enseñanza 180 niños. ¿Qué ahorro tan considerable proporcionamos pues al Gobierno! Sería pues mui justo i equitativo que nos auxiliasen con una cantidad mayor, mientras el mal estado de las escuelas públicas nos obligase a mantener una escuela particular.-

${ }^{74}$ Véase Collier, Simon: Chile: The Making of a Republic..., 2003, p. 116 y Pérez Rosales, Vicente: Recuerdos del Pasado, 2006, pp. 393-466.

${ }^{75}$ Collier, Simon: “Chile: La Construcción de una República...”, 2005, p. 164.

${ }^{76}$ Ibídem, p. 163. 
Durante la existencia de la actual jeneración, i hasta que no se hubiese mejorado la moralidad de la venidera, sería de mucha urjencia $^{77}$.

A través de su interlocutor, Anwandter pretendía dar a conocer en Santiago algunos aspectos relevantes de la educación valdiviana y, de esa forma, conseguir que el Estado auxiliara a sus escuelas. Según él, este requerimiento era fundado, ya que el Estado se había beneficiado con el trabajo educacional de los alemanes, ahorrando dinero y sorteando más o menos bien su incapacidad para cubrir la demanda educacional del sur. En ese sentido, y al igual como lo plantearían Cuixart y algunos editorialistas de la $R C$ años más tarde, su argumentación se proponía convencer a los agentes estatales de que la extensión de la enseñanza a los lugares más alejados de la capital dependía de cuán bilateral y cooperativa fuera la relación entre los gobiernos y los particulares.

Imposible saber a ciencia cierta cuál fue la respuesta de Vicuña Mackenna, aunque, a juzgar por los acontecimientos posteriores, la opinión de Anwandter penetró en el inconsciente de los políticos y educadores santiaguinos, pues, como decíamos, la ayuda estatal se hizo cada vez más frecuente. Al mismo tiempo, las solicitudes de subvenciones provenientes de las colonias aumentaron, como también las diferentes herramientas para obtenerlas. Entre ellas, la más efectiva era recalcar que en los establecimientos alemanes se educaban muchos hijos de chilenos, y que, por ende, su aporte a la educación no era sólo colonial, sino nacional.

Así lo podemos apreciar en una solicitud de subvención firmada en noviembre de 1892 por Cristián Corneli, presidente de la escuela alemana de Temuco, cuyo directorio suplicaba

\begin{abstract}
Modestamente se digne el Supremo Govierno incluya en el presupuesto del año entrante una suma destinada para subvencionar a la escuela Alemana de Temuco, que existe en esta poblacion ia desde el año 1887, aumentandose de año en año el número de los alumnos, habiendo tambien dicha escuela ia proporcionado enseñanza a muchos discipulos chilenos i comprometiendose la sociedad [a] enseñar gratuitamente hasta 20 alumnos de nacionalidad chilena durante el tiempo que
\end{abstract}

77 "Carta de Karl Anwandter a Benjamín Vicuña Mackenna y su Respuesta, Valdivia, 18 de Mayo 1867”, en Biblioteca y Archivo Histórico Emilio Held Winkler de la Liga chileno-alemana, p. 8. Agradezco a Patricio Bernedo el haberme informado sobre la existencia de este documento. 
el establecimiento estuviese subvencionado por el Supremo Govierno $^{78}$.

Que los alemanes de Temuco estuvieran dispuestos a becar a veinte chilenos para que se formaran en su establecimiento, es una señal de cómo una colonia específica podía ayudar al desarrollo global del país, y transformarse en un puente vinculante entre el centro político y la periferia regional.

El parecer de Corneli era compartido por otros colonos, si bien en algunas veces el tono suplicante del temuquense podía ser combinado con uno más directo e incisivo. Efectivamente, algunos alemanes creían que las solicitudes de subvenciones eran un mecanismo para exigir ciertos derechos antes que para requerirlos, aduciendo que si el Estado se beneficiaba con las escuelas coloniales, entonces a éstas les correspondía recibir un apoyo más significativo por parte del ministerio de Instrucción Pública.

Los directores de la escuela alemana de Los Ángeles eran de esta última idea. En una larga solicitud de diciembre de 1894, alegaban que, de un día para otro y sin previo aviso, el Estado había decidido paralizar el apoyo a su institución. Esto los había obligado a impetrar una serie de auxilios extraordinarios:

Todo lo espuesto, [...] nos obliga [a] solicitar del Supremo Gobierno ayuda activa i eficaz. Para esto solicitamos lo siguiente: Seis mil pesos (\$6000) para la construccion de un nuevo local, que sería construido segun los modelos de las escuelas alemanas, ajustado a los principios i reglas de la hijiene i de la moderna enseñanza pedagójica. Item mas, dos mil pesos (\$2000) de subvencion anual para añadirlos a las erogaciones, con que contribuye la colonia para el sueldo de profesores. Item mas, un mil pesos (\$1000) de subvencion anual atrasada a contar desde el $1^{\circ}$ de Enero [de] 1893 hasta hoi, que se necesitan indispensablemente para pagar a los profesores honorarios devengados.

Como si eso fuera poco, concluían su solicitud haciendo comparaciones odiosas entre el gobierno de la época, encabezado por Jorge Montt, y los de sus antecesores (el principal de los cuales era el del principal enemigo de Montt, José Manuel Balmaceda), quienes, al parecer, no habían dudado en apoyar una y otra vez a la colonia de Los Ángeles:

Advertimos con todo respeto, que si los Gobiernos anteriores al de V.E. [Jorge Montt] prestaron proteccion decidida al

${ }^{78}$ A.N.M.I.P., volumen 870, ff. 152-152v. 
mantenimiento de este colejio tan importante, hasta cierto punto es de esperar del vuestro que se la presteis como los otros; de lo contrario la situacion se haria insostenible ${ }^{79}$.

A su vez, había casos en que el Estado exigía mayor compromiso de parte de los colonos. A principios de 1897, distintos agentes estatales participaron en una tramitación de solicitud de subvención de la escuela San Luis de Contulmo, la cual no fue precisamente breve. Esto último se debió a que los diferentes intercesores quisieron confirmar detalladamente que el colegio cumpliera todas las exigencias del ministerio, una de las cuales hacía alusión a la obligatoriedad de la enseñanza del castellano en los establecimientos del país.

El gobernador de Cañete fue el primero de estos agentes que se informó sobre el asunto, concluyendo que el educador encargado impartía todas sus clases en alemán, y que, por ende, los estudiantes no tenían la oportunidad de aprender "también el idioma nacional"80. Pese a ello, el gobernador creía que la escuela era un aporte para la comunidad de Contulmo, y que el problema lingüístico podía solucionarse fácilmente con una subvención de 500 pesos, que serviría, entre otras cosas, para financiar a un profesor de castellano. Fue así como la solicitud pasó a manos de la Inspec-

${ }^{79}$ A.N.M.I.P., volumen 1079, sin fojas exactas. El subrayado es del original. Federico Maetschil, presidente de la escuela alemana de La Unión, compartía algunos de los puntos de vista de los sostenedores de la escuela alemana de Los Ángeles. En una solicitud de octubre de 1895, señalaba: "El Supremo Gobierno, auxilia ala sociedad 'Escuela Alemana' de la Union, con una subvencion de ochocientos pesos anuales, cantidad, que si bien es cierto que apoya la existencia del establecimiento, tambien lo es que ella es demasiado insignificante, en atencion a los gastos crecidos que demanda el sostenimiento de la escuela i tomando el consideracion el beneficio que ésta reporta al departamento i el gasto que ahorra al erario nacional, el ser ella sostenida con el sacrificio pecuniario de los vecinos mismos. [...] Para el año entrante el número de dicipulos aumentará al menos un veinticinco por ciento i habrá necesidad de adquirir otro profesor para la escuela, adquisicion en la cual no podrá pensar la sociedad si no obtiene un auxilio mas formidable del Supremo Gobierno i acaso verá desfallecer las esperanzas que ella fijaba en un establecimiento que ha fundado i sostenido a fuerzas de perseverancia i sacrificio durante cerca de cuarenta años en beneficio de sus hijos i buenos ciudadanos, habiendo con el conseguido formar de ellos hombres útiles. En virtud de lo espuesto i confiando en la benevolencia con que el Supremo Gobierno ha acojido siempre solicitudes de este jénero, demostrando con ello el alto interés que tiene en la instruccion en el pais, vengo como representante de la sociedad "Escuela alemana de la Union” en rogar a Vuestra Exelencia, se digne acordar a la sociedad nombrada, [...] aumentar a un mil doscientos pesos la subvencion actual de ochocientos pesos por año, que goza”. En ibídem, ff. 102v-103.

${ }^{80}$ A.N.M.I.P., volumen 1164, sin foja exacta. 
ción General de Tierras y Colonización, cuyo dictamen fue positivo, aunque no sin antes imponer ciertas condiciones a cambio:

En la población de San Luis de Contulmo se ha fundado por la colonia alemana ahí existente una Escuela, regentada por un joven profesor alemán, pagado por suscripción común de los vecinos y el cual se dedica con particular esmero á la enseñanza de los niños que concurren al establecimiento en número de 60, término medio. Sucede que la enseñanza de los ramos de instrucción primaria se hace toda en lengua alemana, de donde resulta que á los niños se les hace difícil sino imposible el aprendizaje del castellano. Con motivo de haberse representado al infrascrito, por varios de los citados colonos, el deseo de obtener del Supremo Gobierno una pequeña subvención anual para ayudar al sostenimiento de la referida escuela, les manifesté mi buen deseo de dirigirme á V.S. en demanda de lo que ellos solicitaban, á condición de que establecieran la enseñanza forzosa del idioma nacional, á fin de poner á los futuros jóvenes desde la niñez en contacto con nuestros connacionales, sacándolos desde temprano del retraimiento en que se han mantenido sus padres los actuales colonos, debiendo al mismo tiempo recibir i educar, sin retribución alguna, seis niños hijos de nacionales, todo lo cual fué aceptado por los solicitantes ${ }^{81}$.

Es interesante destacar que este informe llegó a manos de Carlos Morla Vicuña, a la sazón ministro de Relaciones Exteriores, y que fue él quien lo envió al ministro de Instrucción Pública. De ese modo, tenemos que, por lo menos, cuatro tipos de agentes estatales participaron en el proceso que interesaba a la escuela de Contulmo, y que cada uno entregó su impresión sobre cuáles debían ser las reformas que debía implementar el establecimiento para recibir la ayuda del Estado. Para los personeros del gobierno la tramitación de esta subvención no era un tema menor, pues detrás de ella había materias mucho más relevantes que una simple solicitud. En efecto, lo que se estaba discutiendo era cómo potenciar la educación impartida por los extranjeros, sin que sus estudiantes vivieran aislados de la realidad chilena. $\mathrm{O}$, en otras palabras, cómo lograr infundir el espíritu nacional en aquellos lugares donde al Estado central se le hacía imposible llegar con sus propias herramientas ${ }^{82}$.

${ }^{81}$ Ibídem, sin fojas exactas.

${ }^{82}$ Aquí seguimos la propuesta conceptual de Benedict Anderson en Comunidades Imaginadas. Reflexiones sobre el Origen y la Difusión del Nacionalismo, 2000, sobre todo el planteamiento del capítulo X. Aunque no encontramos la información 


\section{El caso de Concepción y sus alrededores}

Los alemanes no eran los únicos sostenedores particulares de colegios regionales en el sur del país. También lo eran algunas personas que no pertenecían a una colonia o a una religión específicas, y simplemente deseaban educar a una población con diferentes creencias y aspiraciones. Entre ellos, como decíamos al principio de este apartado, los más sobresalientes se ubicaban en Concepción y sus alrededores, zona en la cual existía un número significativo de establecimientos privados, tanto en la educación primaria como en la secundaria.

A fines del siglo XIX, Concepción era la tercera ciudad del país, aventajada sólo por Santiago y el, en ese entonces, todavía pujante puerto de Valparaíso ${ }^{83}$. El progresivo aumento de la población urbana comenzaba a cobrar fuerza en la capital penquista, la cual hacía esfuerzos extraordinarios para satisfacer la creciente demanda en salud, vivienda y educación. En cuanto a esto último, el Estado intentaba cubrirla mediante la creación de nuevos establecimientos, pero, al igual que en los otros casos que hemos visto, se le hacía imposible sostener todos los costos que ello requería. Dado lo anterior, la ayuda de los particulares era del todo vital.

Obviamente, éstos creían que el Estado debía auxiliarlos en el sostenimiento de sus escuelas y colegios (ya fuera a través de los denominados "materiales de apoyo" 84 o de las subvenciones anuales en dinero), a pesar de que sabían que para lograr dicho apoyo era necesario demostrar constantemente sus cualidades e, incluso, cierta lealtad con el gobierno de turno. Pues, mal que mal, en el caso de esta clase de sostenedores privados, la decisiones políticas jugaban un papel más activo que en el de los misione-

correspondiente a la entrega de la subvención solicitada por los colonos de Contulmo, es muy probable que ésta sí se haya llevado a cabo, ya que, en un informe redactado por el Inspector de Escuelas de Arauco en mayo de 1902, se hace alusión a que la escuela cumplía satisfactoriamente la principal condición impuesta por la Inspección General de Tierras y Colonización: la enseñanza del castellano. Dice: "He visitado el establecimiento que la Colonia Alemana de Contulmo sostiene para dar la conveniente instruc[ción] a sus hijos. [...] Todos los ramos, entre ellos el cultivo de los colmenares, de las hortalizas i huertas, se enseñan indiferentemente en Castellano i en aleman”, en A.N.M.I.P., volumen 1567, sin foja exacta.

${ }^{83}$ El Censo General de la República de Chile de 1907 arrojó los siguientes datos demográficos: Santiago: 463.775 habitantes; Valparaíso: 190.251 habitantes; Concepción: 72.380 habitantes, en www.memoriachilena.cl

${ }^{84}$ Efectivamente, el Estado también subvencionaba entregando "materiales de apoyo", esto es, libros de Historia, Silabarios, Catecismos, Mapas, etc. Véase, por ejemplo, A.N.M.I.P., volumen 720 . 
ros y colonos, a tal punto que muchos requerimientos podían estar teñidos por los acontecimientos públicos de la época.

Las consecuencias de la guerra civil de 1891 permiten demostrar esta afirmación. Sabido es que este conflicto dividió a la sociedad chilena en dos grupos antagónicos, permeando los más diversos escenarios y actores históricos. Por su relevancia y significación ideológica, la educación nacional fue uno de los escenarios donde la guerra golpeó con más fuerza, cuestión que a los encargados de la Sociedad de Instrucción Primaria (SIP) de Concepción les tocó vivir en carne propia, cuando sufrieron las consecuencias políticas de la "dictadura” de Balmaceda y las repercusiones económicas de la postergación de la Ley de Presupuesto Nacional de 1891.

Para 1890, la SIP de Concepción recibía una subvención anual de dos mil pesos ${ }^{85}$, la que se había alcanzado, en gran medida, gracias a que el directorio de la Sociedad era "adicta” a Balmaceda ${ }^{86}$. Esta situación había comenzado a cambiar al evidenciarse que la posición del presidente era cada vez más insostenible, y que sus días en el poder estaban contados. En agosto de 1891, la caída de Balmaceda se hizo realidad ${ }^{87}$ y, poco tiempo después, el pago de la subvención acordada a la Sociedad se suspendió. Ella se vio en la obligación de solicitar un empréstito para no paralizar "las tareas de la enseñanza en todas o en algunas de las escuelas que hay en funciones" ${ }^{88}$. Tres meses más tarde, cuando las penurias llegaron a un punto sin retorno, los directores decidieron dar un giro a su posición política, e intentaron conversar con los encargados del nuevo gobierno. ¿De qué manera? De la manera más práctica y eficaz que, para entonces, podían expresar: el cambio rotundo de su discurso, tanto en la forma como en el fondo.

Según una carta de Gregorio Burgos, presidente de la SIP de Concepción, fechada el 2 de diciembre de 1891, la Sociedad se había visto en la obligación de aceptar las modificaciones que Balmaceda había introducido en su directorio, debido a que ellas eran las únicas que podían garantizar que las escuelas continuaran "sus tareas con regularidad". Ahora, en cambio, la SIP se daba cuenta del profundo error que había cometido de la “Dictadura”, y solicitaba encarecidamente que el nuevo gobierno le brindara su ayuda:

${ }^{85}$ Véase Lei de Presupuestos de los Gastos Jenerales de la Administracion Pública de Chile para el Año de 1890, 1889.

${ }^{86}$ Véase A.N.M.I.P., volumen 870, f. 28v.

${ }^{87}$ Sobre la caída de Balmaceda, véase Baeza, Andrés: "La Muerte de José Manuel Balmaceda. ... El Sacrificio es lo Único que Queda al Honor del Caballero”, 2006, pp. 237-261.

${ }^{88}$ Ibídem, f. 29. 
Invocando el precedente de que el Excmo. Gobierno en algunos ramos del servicio publico ha decretado que se observen los presupuestos del año último [1890] me permito en nombre de la Sociedad [de] Instrucción Primaria de Concepción solicitar del Supremo Gobierno que digne expedir el decreto i orden de pago respectivo a fin de que sean entregados al Tesorero de dicha Sociedad hasta el $1^{\circ}$ de Enero próximo las subvenciones que quedan insolutas despues del último pago efectuado durante la dictadura a razon de dos mil pesos anua$\operatorname{les}^{89}$.

Es decir, la Sociedad no pedía un gravamen extraordinario al erario, sino la entrega "de una asignación acordada en el presupuesto i que solo ha dejado de percibirse por la situación anormal que acaba de terminar"90. Burgos, entonces, parecía consciente de que para conseguir la subvención, era necesario bajar el perfil de la antigua lealtad de la SIP de Concepción al “dictador" caído, pues, de otro modo, los nuevos administradores de la nación podían negarse a concretar la entrega del dinero. Es cierto que es muy difícil saber a ciencia cierta cuál era la posición política exacta de Burgos antes de la revolución, aunque es bastante claro que no se disgustó mayormente con el cambio de directorio sufrido por la Sociedad en 1890. En ese sentido, su iniciativa y la de sus compañeros al momento de solicitar la subvención habría sido más pragmática que ideológica, muy semejante a la asumida por algunos misioneros del sur, cuya máxima aspiración era contar con el dinero estatal costase lo que costase ${ }^{91}$.

Otro tema importante relacionado con la educación particular en Concepción contenía, como adelantáramos, un trasfondo que hoy denominaríamos "regionalista”. Este se fundaba en el hecho de que los penquistas solían sentirse abandonados por el Estado central, ya que, en su pensar, las arcas fiscales preferían beneficiar a las escuelas y colegios de Santiago y Valparaíso antes que a los suyos. Para una ciudad orgullosa como Concepción, la constatación de que santiaguinos y porteños pudieran disfrutar de mayores privilegios económicos, era señal de que el proyecto nacional no era en verdad democrático, y que, por lo mismo, vivir alejados de la capital era un sino negativo que continuaba persiguiéndolos.

${ }^{89}$ Ibídem, ff. 30-30v.

${ }^{90}$ Ibídem, f. 31.

91 Véase supra, p. 47, referente al capuchino José de Potries. Finalmente, la posición de la SIP de Concepción trajo buenos resultados, ya que, el 11 de diciembre de 1891, el nuevo gobierno aceptó pagar las mensualidades insolutas desde el $1^{\circ}$ de agosto de 1891 hasta el 31 de diciembre del mismo año, véase ibídem, f. 27. 
La primera noticia que hemos encontrado con respecto a esta posición "desfavorecida" de Concepción es de junio de 1900, y proviene de una carta dirigida por el Liceo de Niñas de Chillán al ministro de Instrucción Pública. En ella, su director plantea las dificultades económicas que había debido sobrellevar su establecimiento para responder a los cada vez más exigentes niveles de "la instruccion de la mujer en Chile"92 . A pesar de que el Estado había facilitado la casa en que funcionaba el colegio y que, incluso, éste recibía una subvención anual de seis mil pesos, el sostenedor estaba convencido de que, en comparación, su liceo no tenía las mismas herramientas educativas y económicas que los Liceos de Niñas de Santiago y Valparaíso.

En efecto, ni siquiera las subvenciones extraordinarias acordadas por algunos gobiernos en el pasado, habían sido suficientes para terminar las remodelaciones del edificio exterior y de las salas de clases, las cuales, por lo demás, sólo iban en beneficio del fisco, ya que a él le pertenecía finalmente la estructura del establecimiento. ¿Cuál era, entonces, la solución? Según el director, lo más responsable y práctico que podía hacer su liceo era abandonar su calidad de particular, y pasar completamente a manos del Estado, como era el caso de los liceos fiscales de Santiago y Valparaíso. En su opinión, ésa era la única fórmula para superar los problemas financieros y acercarse al nivel académico que mostraban los liceos femeninos estatales de las dos principales ciudades del país. Empero, y a pesar de que esta solución podía ser realmente efectiva, no cabe duda que, para el sostenedor, el principal responsable de esta situación era el Estado y su falta de imparcialidad al momento de repartir los fondos del erario:

Si se toma en cuenta que el sostenimiento de los Liceos de Niñas de Santiago i Valparaiso imponen por término medio al Estado un desembolso de $\$ 43.668$ al año, se comprenderán las estrecheces por que ha debido pasar el Liceo de Niñas de Chillan, que con una entrada anual de $\$ 12.000$ ha mantenido dos secciones preparatorias i cinco años de humanidades, ademas de las clases de piano i pintura. Esta situacion no puede prolongarse por mucho tiempo, so pena de que sobrevenga el desaliento i se esterilicen muchos nobles i jenerosos esfuerzos, en vista de la carencia de fondos para hacer frente a las exijencias cada dia mayores de la enseñanza secundaria $^{93}$.

\footnotetext{
92 A.N.M.I.P., volumen 1409, sin foja exacta.

${ }^{93}$ Ibídem, sin foja exacta.
} 
Con estas palabras, el director pretendía ejemplificar que los centros educacionales de Chillán no recibían los mismos privilegios que los colegios fiscales santiaguinos y porteños, y que, por lo tanto, la distribución de los dineros era más subjetiva y parcial de lo que debía ser. Así, pues, esta discusión no giraba necesariamente en torno a qué tipo de enseñanza - la fiscal o la privada - era mejor, sino en cómo lograr que las subvenciones a los colegios más alejados de la capital aumentaran, sobre todo cuando se hacía evidente que éstos prestaban "importantisimos servicios a los padres de familia"93 y, por qué no decirlo, también al Estado. De otra forma no se explica que el Liceo de Niñas de Chillán estuviera dispuesto a ceder sus derechos única y exclusivamente si "el Fisco lo coloca[ba] en la misma categoria que los Liceos de Niñas de Santiago i otras ciudades" 95 .

El Liceo Americano de Señoritas de Chillán fue, finalmente, otro de los establecimientos penquistas que llevó a la práctica el argumento regionalista. No obstante, a diferencia del caso anterior, sus sostenedores no creían que vivir lejos de la capital fuera una condición gravosa, sino una oportunidad para demostrar que los colegios regionales podían ser tan calificados como los de Santiago o Valparaíso. Así lo comprueba una solicitud de subvención de noviembre de 1902, en la que una orgullosa María Espíndola, directora del colegio, solicitaba una subvención para comprar un gabinete de física, recalcando que el Estado había apoyado anteriormente a su institución al ver que su "buena dirección", su "exelente profesorado" y sus "espléndido[s] resultado[s] en [los] exámenes universitarios" llenaban "una verdadera necesidad pública en” Chillán ${ }^{96}$.

Un año después, el mismo liceo dirigía "al público" un nuevo "Prospecto", en el cual se resaltaba otra vez la importancia de dicho establecimiento para la región. Como si se tratara de un producto comercial, una de las secciones comentaba un premio recibido en 1902 por el Liceo Americano de manos del "Comité de la Esposicion Internacional de Material de Enseñanza”, distinción que, según el folleto, se había debido a dos razones: “en primer lugar, porque es un establecimiento particular i segundo, porque es de provincia" ${ }^{\prime 7}$. La complementación perfecta entre estas dos características le había permitido ser el único establecimiento, desde Chillán a Punta Arenas, en conseguir dicho reconocimiento:

Los padres de familia podrán, ahora convencerse aun mas, que el Liceo Americano es en el "Sur de Chile" un estableci-

\footnotetext{
${ }^{94}$ Ibídem, sin foja exacta.

${ }^{95}$ Ibídem, sin foja exacta.

96 A.N.M.I.P., volumen 1570, sin fojas exactas.

${ }^{97}$ A.N.M.I.P., volumen 1830, sin foja exacta. Las cursivas son del original.
} 
miento donde pueden educar sus hijas con resultados positivos, teniendo la completa seguridad de que no habrán perdido su tiempo. [...] Esperamos que al fin del año que empieza [1903], estos mismos esfuerzos, tanto de profesores como de las alumnas, nos han de dar un resultado, sino superior al del año pasado, al ménos que nos deje satisfechos de la labor realizada $^{98}$.

Con los ejemplos citados arriba, hemos satisfecho la necesidad de dar un panorama más o menos completo de cómo operaban las solicitudes regionales a fines del siglo XIX y principios del XX. Los dos grupos analizados — colonos alemanes y sostenedores penquistas - confirman que los requerimientos eran sumamente variables, al igual que las circunstancias de cada uno de aquellos. No obstante, todos compartían la misma necesidad de contar con la ayuda económica del Ejecutivo, por lo que muchas veces sus estrategias o herramientas discursivas podían repetirse.

Unos y otros, por ejemplo, tenían y expresaban la impresión de que su radicación en determinadas zonas era una ayuda de primera importancia para la labor educacional del Estado, ya que, debido a las distancias geográficas y a la falta de recursos, a éste se le hacía imposible cubrir toda la demanda estudiantil. Esta constatación no quiere decir, empero, que sus solicitudes fueran siempre oídas y aceptadas por el ministerio de Instrucción Pública. De hecho, muchas de ellas podían perderse en los rincones burocráticos si no contaban con el apoyo explícito de los agentes estatales que residían en su localidad.

Gobernadores, intendentes y visitadores de escuelas eran algunos de esos agentes, y su intervención era tan importante como la participación de los sostenedores particulares. Contar con su colaboración podía tomar algún tiempo, y, una vez alcanzada, había que estar dispuesto a hacer todo lo posible para mantenerla. Por ello, no es extraño que, en ciertos casos (como fue el de la Sociedad de Instrucción Primaria de Concepción después de la guerra civil de 1891), los privados se acomodaran a las lealtades políticas que, de una u otra forma, rondaban en el mercado de subvenciones.

Ahora bien, como veremos a continuación, estas estrategias no eran exclusivas de las regiones alejadas de la capital, sino que también se repetían en las solicitudes efectuadas por los colegios particulares de Santiago, entre los cuales los más sobresalientes eran los establecimientos femeninos secundarios.

${ }^{98}$ Ibídem, sin foja exacta. 


\subsection{Colegios secundarios femeninos de Santiago}

En la década de 1890 existían en Santiago diversos colegios secundarios femeninos, cuyas directoras debían superar el mismo trámite de solicitud de subvención que los sostenedores de establecimientos misionales o regionales. Decimos directoras porque, en su mayoría, estos colegios eran regidos por mujeres que dedicaban su vida a desarrollar la instrucción del sexo femenino. Esto no quiere decir que sus objetivos fueran necesariamente diferentes de los de sus pares masculinos, ya que, en general, las sostenedoras secundarias aspiraban a que el ministerio las considerara de la misma forma que a los colegios de varones, tanto curricular como económicamente.

A lo anterior se debe que la principal estrategia de las secundarias fuera remarcar la importancia de sus establecimientos en un mundo que, paulatinamente, comenzaba a aceptar a la mujer. El hecho de que la enseñanza femenina fuera cada vez más exigente y acabada, era señal de cuánto se había perfeccionado el conocimiento a lo largo de toda la centuria decimonónica, como también una prueba de que la evolución democrática de la sociedad chilena empezaba a rendir sus primeros frutos. Así lo comprobaba, por ejemplo, el ingreso, lento pero seguro, de las primeras señoritas a las aulas de la UCH, en cuya formación las educadoras secundarias habían cumplido un papel de primera importancia.

Los colegios femeninos particulares requerían mayor financiamiento del que necesitaban los establecimientos primarios ${ }^{99}$. La entrada en vigencia del sistema concéntrico obligó a las sostenedoras secundarias a asimilar la nueva metodología de enseñanza, y, en ciertos casos, a capacitar y contratar a nuevos profesores. Esto conllevó un aumento de sus presupuestos anuales, además de un alza del número de solicitudes de subvención y de los requerimientos económicos expresados en ellas. El cambio curricular instaurado por Valentín Letelier no podía sino estar ligado a un incremento general de los costos de la enseñanza nacional, y, por consiguiente, de los fondos destinados a ayudar a los particulares que habían puesto en práctica los planes del ministerio.

El caso del colegio Isabel Le Brun demuestra empíricamente esta opinión. En una solicitud de marzo de 1892, su directora comenta lo difícil que había sido para su establecimiento conseguir el nivel académico exigido por el ministerio, y que muchas veces había debido que "hacer gastos superiores” a sus fuerzas para lograr “establecer en mi Liceo el curso completo

${ }^{99}$ Véase A.N.M.I.P., volumen 1977. 
de Humanidades i dotarlo de un laboratorio de química bastante completo i de los aparatos, mapas i demas objetos indispensables para la enseñanza de la Física i de la Historia Natural”"100.

En esta labor había contado con una subvención anual del Estado, la que se había incrementado con el paso de los años debido a sus buenos "precedentes". No obstante, ahora que la puesta en práctica del sistema concéntrico significaría costos extraordinarios para su institución, aquella ayuda anual era insuficiente, y un aumento en los montos acordados se hacía indispensable:

Esta reforma [sistema concéntrico], cuya importancia no puede ponerse en duda, me impone mayores gastos, como que necesito profesores suficientemente preparados en los modernos sistemas de enseñanza. Creo que las consideraciones espuestas serán suficientes para que el elevado criterio de V.E. se posesione de la seriedad de los estudios que se hacen en mi Liceo i se sirva acordar la subvencion anual de diez mil pesos, que dejo solicitada ${ }^{101}$.

A diferencia de los católicos ultramontanos, Isabel Le Brun apoyaba los planteamientos teóricos de Letelier y del Estado docente, aunque no sin antes declarar que la implementación satisfactoria de ellos dependía de cuánto dinero estuvieran dispuestos a gastar los particulares y los agentes estatales. Su argumentación estaba teñida, entonces, por razones económicas antes que curriculares, marcando una diferencia notoria con la posición oficial de la Iglesia con respecto a cuál debía ser la relación entre los dos sectores.

Rita Figueroa, directora del Colegio Infantil de Señoritas, tenía una visión similar a la de Isabel Le Brun. En una solicitud de febrero de 1897 señalaba que las "reformas radicales de la instrucción secundaria i en la educacion de la juventud" la habían obligado a pedir la colaboración de algunos profesores titulados en el Instituto Pedagógico, quienes, con sus conocimientos y buena voluntad, la habían ayudado a implementar el sistema concéntrico en su establecimiento. En el poco tiempo que llevaba en práctica el nuevo método, Figueroa se había dado cuenta de "la profunda diferencia que existe entre el sistema de enseñanza antiguo i el nuevo i la necesidad absoluta e imprescindible de dar a este último toda la latitud i la estension que requiere". Pero también había comprobado que "para su completa i cabal implantacion”, el apoyo del Estado era necesario:

${ }^{100}$ A.N.M.I.P., volumen 870, f. 41.

${ }^{101}$ Ibídem. 
El sistema moderno de enseñanza da mucha i mui merecida importancia a la práctica de los estudios i a la observacion; práctica i observacion que hacen necesarios e indispensables buenos gabinetes i muchos útiles, como globos, colecciones de mapas antiguos i modernos, jeográficos, físicos e históricos, etc, etc. Todo esto que estimo de primera i urjente necesidad, no he podido sino en parte reducidísima, proporcionarlo a los Profesores del Estado que lo solicitan para el completo éxito de sus sabias i bien meditadas lecciones haciéndose resentir, sin duda, la introduccion de esta falta de elementos. El Gobierno anterior al de V.E. auxilió a mi establecimiento con la suma de ochocientos pesos, suma demasiado exigua si se toma en cuenta las exijencias que reclaman los nuevos métodos i el nuevo sistema de enseñanza. En esta virtud i confiada en los buenos i magníficos propósitos que V.E. abriga por la instruccion de la mujer, vengo a solicitar i pedir a V.E. que de los veinte i cinco mil pesos consignados en el Presupuesto para auxiliar i difundir la instruccion secundaria en la mujer, asigne al "Colejio Infantil” que dirijo la cantidad de siete mil pesos, cantidad que estimo absolutamente indispensable para la correcta i segura marcha del establecimiento i con la cual satisfaré en lo posible las exijencias que demandan los métodos i el sistema concéntrico de enseñanza ${ }^{102}$.

Los planteamientos de Le Brun y de Rita Figueroa dejan entrever que el financiamiento de los distintos colegios del país repercutía directamente en el nivel de la enseñanza, y que la rivalidad entre los colegios secundarios podía ser un elemento presente al momento de solicitar la subvención estatal. En efecto, la competencia entre las secundarias de Santiago era mucho más explícita que en otros colegios particulares, entre otras cosas porque el número de sus alumnos y la oferta de establecimientos eran, ambos, sumamente extensos.

Las sostenedoras eran parte de un incipiente "mercado" educacional, cuya expresión se debía tanto a la oferta que ellas representaban como a la demanda impuesta por los cada vez más heterogéneos y numerosos alumnos de la capital. La oferta —manifestada en el desempeño de cada establecimiento en el tiempo- jugaba un papel muy importante en la entrega de subvenciones, pues la calidad de la enseñanza de los establecimientos particulares continuaba condicionando, para bien o para mal, el apoyo estatal $^{103}$. Así, la ayuda económica podía tardar más de lo presupuestado si

${ }^{102}$ A.N.M.I.P., volumen 1169, ff. 236-236v.

${ }^{103}$ Véase supra, p. 28. 
el ministerio consideraba que los solicitantes no cumplían con sus estándares ${ }^{104}$. Esto no quiere decir que los niveles de educación fijados por el Estado fueran siempre objetivos o confiables; solamente confirma que, en general, esa era la herramienta más adecuada para saber a quiénes apoyar y a quiénes no.

Las cualidades de las secundarias particulares eran muchas, pero unas eran más consideradas que otras por el Estado. Así, por ejemplo, el hecho de que algunas de ellas sostuvieran instituciones gratuitas o que, por lo menos, estuvieran dispuestas a entregar un número determinado de becas a alumnas de bajos recursos a cambio de las subvenciones, era una característica bastante valorada por los agentes estatales. ¿Por qué? Porque de esa forma el Estado permitía que no pocas niñas ingresaran a un colegio que cumplía con todas las exigencias del ministerio y, con ello, abría las puertas para que la educación se convirtiera en una herramienta democratizadora y equitativa.

Y así lo comprendían también los propios particulares. A diferencia de lo que ocurre hoy en día con ciertos colegios particulares, el fin de lucro no era un tema relevante para los sostenedores de los centros privados. Misioneros, colonos, regionalistas y secundarias no parecían interesados en obtener utilidades con sus respectivos establecimientos. Es cierto que, en este último caso, la mayoría de las alumnas pagaban por sus matrículas. Sin embargo, el dinero recogido por esta vía no era demasiado, y, casi siempre, se destinaba a hacer inversiones en la propia institución.

La verdadera aspiración de las directoras era, entonces, fomentar el nivel educacional de sus dirigidas y lograr que sus instituciones fueran reconocidas por la sociedad y el Estado. De una otra forma, pensaban que la relación entre los agentes gubernamentales y sus colegios debía ser de mutua cooperación, sin importar demasiado los colores políticos o las diferencias ideológicas ${ }^{105}$.

${ }^{104}$ La tardanza en los pagos de las subvenciones era un tema que preocupaba constantemente a las sostenedoras de colegios femeninos, sobre todo cuando ellas ya habían sido aceptadas por el ministerio. Véase, por ejemplo, A.N.M.I.P., volumen, 870, f. 43.

${ }^{105}$ Según Mercedes B. Turenne, directora del liceo La Ilustración, con las subvenciones se beneficiaban tres grupos diferentes: el Estado, las familias y el propio establecimiento que requería la ayuda estatal. En una solicitud fechada el 10 de noviembre de 1900, decía lo siguiente: "Si el Estado acuerda a mi establecimiento una subvencion anual de veinte mil pesos, se abrirá en él un medio internado para cien alumnas que pagarian una pension de quince pesos, igual a la que se cobra en los tres colejios oficiales de esta Capital, i a las niñas que cubrieran esa pension se proporcionaría una instruccion tan esmerada i útil como la que se suministra en este Colejio. Esta proposición, Señor Ministro, conviene en igual forma al Estado, porque con menos a [sic, de] la mitad de lo 


\section{4. ¿A qué criterios se ajustaba el Estado para otorgar las subvenciones?}

(1888-1920)

El sostenimiento i mejoramiento de las instituciones docentes
de oríjen individual, [...] dependen, en realidad de la
mayor o menor largueza con que el Estado concurra a
fomentarlas, siendo a la vez esta largueza una considerable
economía, porque, estinguidas o simplemente debilitadas
aquellas instituciones, nace para el Estado la necesidad
ineludible de costear por sí mismo otras que
vengan a reemplazarlas.

Fanor Velasco, Inspector de establecimientos subvencionados

(Ministerio de Instrucción Pública, volumen 1409)

Solicitar la subvención del Estado no significaba necesariamente recibirla. Ya veíamos que ciertas peticiones podían demorar en llegar al ministerio de Instrucción Pública, y que, en muchos casos, las investigaciones en terreno de los visitadores de escuelas podían arrojar resultados negativos para las aspiraciones de los particulares. Cuando esto sucedía, las posibilidades de contar con el auxilio del gobierno disminuían considerablemente, más aún si las “faltas” del establecimiento se debían a razones académicas o curriculares. A medida que los colegios privados fueron aumentando en número, los criterios para otorgar las subvenciones se fijaron más detenidamente, cuestión que, en definitiva, consolidó la tendencia a que sólo algunas instituciones recibieran la ayuda estatal.

Cabe señalar que el monto de las subvenciones formaban parte de la Ley de Presupuesto General de la Nación que se dictaba cada año, por lo que en el proceso de asignación participaban tanto el Ejecutivo como el Legislativo. En el desglose de las partidas — que eran más o menos nominativas, según el caso - la opinión del ministerio de Instrucción Pública debía ser relevante, ya que era él quien manejaba la información relativa a los colegios particulares y a los montos solicitados por sus sostenedores. Sin embargo, al igual como ocurría con otros ámbitos del presupuesto, los congresistas tenían iniciativa para proponer gastos públicos, y, por lo tanto,

que gasta actualmente en cada uno de aquellos liceos, dotaría a la ciudad de un establecimiento análogo; a las familias, por que aumentaría considerablemente el número de las jóvenes que podrian educarse, i a mi propio establecimiento, por que con la subvencion podría este imprimir mucho vigor al movimiento de progreso que ha realizado en la enseñanza femenina”, en A.N.M.I.P., volumen 1409, sin fojas exactas. 
podían plantear modificaciones a partidas ya existentes o la introducción de nuevas.

Pues bien, como suele ocurrir en cualquier régimen parlamentario, el contenido y alcance de las leyes había de ser negociado entre ambos poderes. Y así quedó de manifiesto, por ejemplo, en febrero de 1894, cuando la administración de Jorge Montt nombró una comisión compuesta por Diego Barros Arana, Máximo del Campo y Domingo Amunátegui Solar, para que "dictaminara acerca de las peticiones que las directoras de los colejios de instruccion secundaria para niñas en Santiago" habían presentado ese año al ministerio. Su misión consistiría en averiguar las cualidades de cada uno de estos establecimientos y luego decidir de qué forma se repartiría "la suma de quince mil pesos acordada con este objeto por el Congreso Nacional” 106 .

Los resultados de la comisión, dados la luz en abril de 1895, determinaron que el dinero fiscal se distribuyera entre nueve establecimientos de secundarias. Los más favorecidos fueron aquellos que estaban dispuestos a recibir un contingente más elevado de becadas en sus aulas, confirmando que la gratuidad de la enseñanza era un tema de primera importancia para los agentes del Estado ${ }^{107}$. Ahora bien, ¿quiénes eran estas becadas? ¿Cómo se lograba obtener una beca en un colegio particular? ¿Quiénes las entregaban? ¿Qué clases de becas existían?

A la par que los colegios particulares secundarios solicitaban la subvención de los gobiernos, familiares de estudiantes comunes y corrientes realizaban el mismo ejercicio para obtener becas en esos colegios. En general, quienes pedían estas becas eran padres, abuelos o tíos de los aspirantes, ya que, de ese modo, se daba un carácter más serio a los requerimientos. Como ocurría con el ítem de las subvenciones, los solicitantes de becas debían exaltar las características académicas de sus representados, y demostrar que, sin el beneplácito del Estado y la anuencia de los privados, se les haría imposible continuar sus estudios. Es decir, un buen nivel curricular y una evidente falencia económica eran dos aspectos vitales para conseguir dicho objetivo.

Pero también había casos en que la historia familiar podía pesar al momento de pedir una beca. Mediante decretos gubernamentales y legislativos, el Estado había becado históricamente a los parientes de los denominados "servidores de la patria" en los mejores centros educacionales, en señal de gratitud y de recompensa por los servicios prestados en diversas áreas,

106 A.N.M.I.P., volumen 870, f. 226.

107 Véase A.N.M.I.P., volumen 1079, f. 6. 
entre las cuales la militar era la que daba lugar al mayor número de solicitudes.

Así lo comprueba, por ejemplo, una carta dirigida en febrero de 1895 por Avelina Bravo al ministerio de Instrucción Pública, en la que dice lo siguiente:

Avelina Bravo, hija del antiguo Teniente Coronel de Ejercito don Juan José Bravo, viuda del Ministro de Aduana i Tesoreria, unidas del Tomé Don Andres Avelino Araya a V.E. con el devido respeto espongo: que deseando dar educacion a dos nietecitas Huérfanas; espero que V.E. se sirva concederme dos becas internas en el Liceo de la Señora [Isabel] Le-Brun atendiendo a los muchos servicios que mi Padre i esposo prestaron al pais, ya en tiempo de la Independencia, ya posteriormente, tanto en nuestra patria, como en el Perú. Cuando la espedicion del Ejército Restaurador a dicho pais ${ }^{108}$, mi finado esposo proporcionó veinte mil pesos [en] ropa, víveres i todo cuanto el Ejército solisitó de su jenerosidad, hasta el punto de perder sus intereses por atender i servir con celo i desinteres los de su patria, como consta por documentos i en su hoja de servicios. Por cerca de treinta años desempeñó mi finado esposo con reconocida honradéz diversos empleos de hacienda, no legando a sus hijas otra cosa que un nombre honorable i el bello ejemplo de buen servidor a su patria. A mas, hago precente a V.E. que me ligaban relaciones de proximo parentesco con los ilustres jenerales O’Higgins i Riquelme, cuyos servicios a la causa de la Independencia de nuestra patria, creo inoficioso enumerar. En merito de lo espuesto vengo en solicitar las dos becas a que me refiero, para mis dos nietas huerfanas, Ana Teresa y Lucila Vargas Araya; en el Liceo Isabel L[e Brun] de Pinochet. Es justicia ${ }^{109}$.

Sin embargo, las cosas no eran tan fáciles como creía Avelina Bravo. En primer lugar, no todos los sostenedores aceptaban el mismo tipo de

${ }^{108}$ Probablemente se refiere a la Guerra del Pacífico.

109 A.N.M.I.P., volumen 1079, ff. 84-84v. Un caso similar, fechado el 19 de marzo de 1895, señala lo siguiente: “Julia Ramirez viuda del capitan don Felipe Zúñiga, servidor en la guerra del Perú, hija de don José Maria Ramirez, sargento mayor de la Independencia, y hermana de don Eleuterio Ramirez, muerto en el combate de Tarapacá, á S.S. respetuosamente expongo que: careciendo completamente de recursos para dar á mis hijos la educación que necesitan, por no tener otra cosa de que vivir que el escaso montepio que me dejó mi esposo, vengo á solicitar de S.S. para mi hija Ester una beca de media pupila en el colegio de la Señora Isabel Le Brun de Pinochet”, en ibídem, f. $112 \mathrm{v}$. 
becados, obligando al Estado a realizar un trabajo detallado y largo para definir cuál era la demanda específica de estudiantes que podían albergar sus respectivas aulas. En ese proceso, eran los agentes estatales quienes confirmaban los cupos y la disponibilidad de los colegios para aceptar a los becados, ya que era el dinero de las subvenciones el que cubría los gastos de la pensión o de la matrícula de los estudiantes beneficiados. Obviamente, aquéllos podían subir o bajar dependiendo de la calidad de la enseñanza y del nivel de las instituciones; por cierto, en todos los colegios se repetía el hecho de que las becas de internos eran las más costosas para el erario, y las de externos las menos.

Una segunda circunstancia que impedía que la entrega de las becas no fuera tan sencilla como creía Avelina Bravo, residía en que, en ciertas ocasiones, los sostenedores particulares se mostraban reacios a aceptar el mecanismo de selección impuesto por el Estado. Algunos sostenedores consideraban, por ejemplo, que el proceso de selección debía ser anónimo, evitándose de ese modo diferencias odiosas entre los alumnos que pagaban matrícula y quienes no lo hacían. Por ello, creían que el Estado no debía hacer públicas las listas de beneficiados y que, en ciertos casos, era más razonable que la selección quedara en manos de los propios privados, antes que en un Estado indiscreto ${ }^{110}$. Así, pues, lo que estaba en juego era la definición de cuánta participación cabía a los particulares y cuánta a los agentes estatales en esta selección de estudiantes.

El Ejecutivo se pronunció sobre el tema. Mediante una serie de decretos, que definieron el papel de cada uno de los involucrados en la elección de los becados, se intentó, al igual como lo hiciera la comisión de subvenciones de 1894 encabezada por Barros Arana, ordenar más o menos definitivamente los cánones que regirían el sistema de distribución de las becas para secundarios. También se buscó definir cuáles serían los actores principales en este proceso, y, por ende, qué tipo de participación le cabría a cada uno de ellos en las distintas gestiones que rodearían las solicitudes de los futuros becados.

El primero de estos decretos contenía ocho artículos, y su publicación es del 28 de noviembre de 1900 . En los preceptos $2^{\circ}, 3^{\circ}$ y $8^{\circ}$ del reglamento se anotaban las facultades y responsabilidades de los tres grupos que debían participar del proceso: los becados (con la consiguiente "autorización del padre o guardador”), una comisión nombrada año a año por el Estado para "que estudie las solicitudes de becas y recomiende las que deben ser preferidas", y los directores de los colegios subvencionados, 
quienes estarían en la obligación de remitir “mensualmente al Ministerio de Instruccion Pública una nómina de los alumnos agraciados con becas, con expresion de su conducta, aprovechamiento i asistencia”.

El artículo $5^{\circ}$ señalaba que las becas se concederían "por tres años prorrogables por otros tres, a favor de aquellos agraciados distinguidos por su buena conducta i aprovechamiento”. El 60, finalmente, explicitaba tres razones fundamentales para que un becado perdiera el reconocimiento otorgado por el Estado: reprobar "algún examen rendido ante comisiones universitarias”, la no presentación justificada a dichos exámenes y la inobservancia de buena conducta ${ }^{111}$.

Tres meses después, se traspasó al ministerio de Instrucción Pública la responsabilidad de analizar a los candidatos. Esta reforma vino a confirmar que el principal veedor de los becados sería el Estado, tanto en materias curriculares (de ahí la importancia de la examinación oficial) como en materias de selección. En otras palabras, el decreto acentuó la influencia estatal en la educación particular; ya no en su relación de tira y afloja con el Arzobispado, sino en su facultad de escoger entre los aspirantes a becarios.

Pero como lo intentamos demostrar en el apartado anterior, la gran mayoría de los particulares ajenos al cuerpo oficial de la Iglesia (incluidos los misioneros) no consideraban que éstas y otras medidas tendientes a reforzar el poder del Estado docente fueran indebidas. Por más que algunos criticaran los mecanismos de selección empleados por el ministerio, contar con la subvención estatal era más importante que cualquier aprensión política o moral, por lo que, poco y nada, les importaba que sus establecimientos se subordinaran al Estado en materias curriculares y económicas.

Esta posición de los privados era complementada por Fanor Velasco, uno de los principales visitadores de colegios subvencionados secundarios de la capital, quien, a través de un informe fechado el 26 de abril de 1900, abogó porque la relación entre ambos sectores se mantuviera siempre en un plano más pragmático que ideológico. Un año antes, Velasco había hecho referencia a cuáles eran, según el Estado, los tres criterios más importantes que debían cumplir esos establecimientos para recibir la ayuda estatal: adherir al sistema concéntrico, tener una buena infraestructura y contratar un profesorado de calidad ${ }^{112}$. Ahora, en 1900, Velasco iba más allá de esta definición de criterios, y se detenía a explicar detalladamente la conveniencia que podía significar para los gobiernos la definición de una relación cordial y constructiva con los privados.

${ }^{111}$ El decreto íntegro se encuentra en Boletín de Leyes y Decretos del Gobierno (BLDG), Libro LXX, Cuarto Trimestre de 1900, pp. 1309-1311.

112 Véase A.N.M.I.P., volumen 1355. 
De los quince establecimientos de educación secundaria visitados por Velasco, los Sagrados Corazones y La Ilustración eran los únicos situados en edificios "con todas las condiciones apetecibles para su objeto". No obstante, y a pesar de que ninguno de los colegios restantes ocupaba "una casa calculada ad hoc", en todos ellos se notaba un "afan por mejorar en lo posible la salubridad i el aprovechamiento" de los alumnos, que, por lo general, aprendían "en conformidad a los métodos más adelantados"113. En comparación con años anteriores, sostenía Velasco, el nivel de esos establecimientos había aumentado considerablemente, tanto gracias al esfuerzo de los sostenedores y directores como a la ayuda brindada por el Estado.

Según el visitador, el ministerio debía lograr que cada uno de los establecimientos funcionara adecuadamente, y que, en consecuencia, ningún joven se quedara sin educación. De ahí que la ayuda estatal fuera tan necesaria y urgente:

Al auxiliar estos colejios con el dinero nacional, siempre se reserva el Estado el derecho de incorporar en sus aulas un cierto número de niños; i para hacer cesar dificultades que a veces han retardado la entrega del auxilio, conviene tener presente que el objeto principal que el Estado se propone al concederlo, no es que los niños A, B i C sean alumnos de los colejios que lo perciben, sino que se asegure la existencia y se promueva el adelanto de esos colejios. Hayáse o nó recojido al establecimiento el agraciado con una beca i haya o nó el Ministerio de Instruccion Pública usado de su factultad de agraciar, se encuentra en actividad el colejio, $i$ es indispensable ponerlo oportunamente en posesion de los recursos que le han sido acordados ${ }^{114}$.

Precisamente porque los colegios subvencionados daban educación a un amplio sector de la sociedad, es que no sólo los particulares se beneficiaban con el apoyo del Estado, sino también el ministerio. En efecto, en un planteamiento similar al que en 1867 utilizara Karl Anwandter ${ }^{115}$, Velasco comprobó empíricamente que los gastos de las subvenciones no habían sido en vano, y que en ciertas ocasiones el Estado había ahorrado dinero en su monto per cápita:

En Mayo de 1899, el Estado invertia la suma de 30,000 pesos en la subvencion de 9 establecimientos con un total de 630

${ }^{113}$ A.N.M.I.P., volumen 1409, sin fojas exactas.

${ }^{114}$ Ibídem, sin fojas exactas.

115 Véase supra, pp. 52-53. 
alumnas, i hoi esta subvencion alcanza a 41,500 pesos para 1014, distribuidos en 15 establecimientos. El gasto que en la actualidad hace el erario público, ha aumentado en 11,500 pesos; pero habiendo así mismo aumentado los alumnos en 384, está hoi reducido a 40 pesos anuales el egreso de 47 que cada uno de ellos imponía en $1899^{116}$.

Siete meses más tarde, el ministro de Instrucción Pública solicitó a Velasco que visitara el colegio La Ilustración, y que redactara un informe de sus cualidades y defectos. En dicha oportunidad, el visitador repitió que el desarrollo de la educación nacional dependía de cuán unidos trabajaran el Estado y los particulares, y que el aporte de estos últimos podía ser tan efectivo como el del ministerio. En su opinión, el caso de La Ilustración demostraba que las subvenciones incentivaban la calidad y la sana competencia entre los establecimientos agraciados, ya que, si una institución en específico dejaba de cumplir con las exigencias del ministerio, el dinero podía ser distribuido entre aquellas que efectivamente exhibieran un total compromiso con la excelencia académica:

El sostenimiento i mejoramiento de las instituciones docentes de oríjen individual, [...] dependen, en realidad de la mayor o menor largueza con que el Estado concurra a fomentarlas, siendo a la vez esta largueza una considerable economía, porque, estinguidas o simplemente debilitadas aquellas instituciones, nace para el Estado la necesidad ineludible de costear por sí mismo otras que vengan a reemplazarlas. [...] Los gobiernos otorgan hoi el auxilio fiscal, por semestres o trimestres anticipados, a los establecimientos que les inspiran confianza, ya sea en virtud de la reputacion que se hayan conquistado ante el público, ya en virtud del juicio emitido por funcionarios autorizados i competentes. De este modo, se sabe que la proteccion va a favorecer el desarrollo de un colejio que tiene antecedentes que respetar; i los actos posteriores que pueden ser causa de su descrédito, v.g., la relajacion de la disciplina, la ineptitud de los maestros, la instalacion en un local inapropiado, etc., siempre se dan a conocer en una época oportuna para que el auxilio les sea suspendido o retirado ${ }^{117}$.

Los dos informes de Fanor Velasco, unidos al reglamento de becas de noviembre de 1900, confirman que el Estado subvencionaba preferente-

${ }^{116}$ A.N.M.I.P., volumen 1409, sin fojas exactas.

${ }^{117}$ Ibídem, sin fojas exactas. 
mente a la oferta de enseñanza — representada por los distintos colegios particulares del país — aunque también a la demanda estudiantil —a través de las becas-. En ese sentido, la combinación de ambos elementos nos hacen pensar que la relación entre el Estado y los particulares continuaba siendo de mutua dependencia.

Ahora bien, y a pesar de que el papel jugado por los visitadores en la entrega de las subvenciones era de suma importancia ${ }^{118}$, en la puesta en práctica de dicho vínculo el Estado no sólo se apoyaba en los agentes estatales. También, como sabemos, expedía decretos para reglamentar el proceso de las subvenciones, ya fuera en el campo de las solicitudes o en el de las entregas. El 4 de febrero de 1899, se dispuso, por ejemplo, que las asignaciones fueran recibidas por determinadas personas naturales: en el caso de las congregaciones religiosas, por los síndicos de los conventos o monasterios; en el de las sociedades de obreros, por sus presidentes; en el de los colegios particulares, por los respectivos directores; y en el de las demás instituciones, por "sus representantes legales" o por las "personas que exhiban poder ad hoc para percibir"119.

Por otro lado, en octubre de 1903 el Ejecutivo presentó un proyecto de ley para definir ciertos aspectos de la instrucción primaria, uno de los cuales se refería a los requisitos que se debían cumplir para fundar escuelas. En la ocasión, se llegó a la conclusión de que "toda persona, natural o jurídica, a quien la lei no lo prohiba, puede fundar establecimientos de instruccion primaria, sin sujecion a medidas preventivas ni a determinados programas o métodos” ${ }^{\prime 20}$. Al mismo tiempo, el artículo $7^{\circ}$ de aquel Proyecto señalaba que

Toda escuela gratuita de instruccion primaria cuya existencia no se deba a corporaciones o fundaciones de derecho público, o a sociedades constituidas con fondos propios o con dinero especialmente destinado al objeto por donaciones o disposiciones testamentarias, recibirá del Estado una subven-

118 Generalmente, las opiniones de Fanor Velasco eran consideradas por el gobierno cuando éste tomaba decisiones importantes. En una oportunidad, Velasco propuso que se obligara a los colegios particulares a tener un libro de matrícula con los datos de los alumnos, un cuadro con el número de las clases semanales de cada ramo y una contabilidad exacta de la asistencia de los estudiantes. Dos días después, el Estado decretó oficialmente la propuesta del visitador, sin introducirle modificación alguna. Véase A.N.M.I.P., volumen 1554.

${ }^{119}$ Revista de Instrucción Primaria (RIP), año XIII, números 1, 2, 3, Santiago, enero, febrero y marzo de 1899, pp. 135-136.

${ }^{120} R I P$, año XVIII, números $10,11,12$, Santiago, octubre, noviembre, diciembre de 1903, p. 536. 
cion de doce pesos anuales por cada alumno asistente durante ciento ochenta días en el campo i doscientos en las ciudades. [...] Para percibir esta subvencion, la escuela debe someterse a la vigilancia del Estado en cuanto al mínimo de instruccion que en ella se dé121.

Aunque la parte final del documento centralizaba los aspectos básicos de la instrucción primaria en el criterio estatal, este proyecto de ley es una prueba de la disposición de los gobiernos de esa época a aceptar que los particulares tuvieran un papel importante en la educación de los niños y jóvenes del país. De hecho, estar dispuesto a subvencionar a todas las escuelas gratuitas arriba aludidas era un gesto significativo por parte del Estado, más aún considerando que, con el paso del tiempo, ellas se habían ido multiplicando e incluso triplicando. Así, en 1904 más de 160 instituciones obtuvieron la ayuda estatal, de las que más de un 50\% correspondían a dichas escuelas, tales como las de artesanos de Tarapacá y los colegios de la Sociedad de Instrucción Primaria de Santiago ${ }^{122}$.

El incremento de los montos de las subvenciones es analizado en los Cuadros 1 y 1.1., tanto en la variable "nominal” como en la "real”.

El primer cuadro evidencia "nominalmente” el crecimiento paulatino de los distintos presupuestos entre 1892-1905. Por más que en ninguno de esos años el monto de las subvenciones sobrepasara el 5\% del total de Instrucción Pública, no cabe duda que el ministerio vio cada vez con mejores ojos la participación de los privados en la educación nacional. De otra manera, no se explica que el número de instituciones auxiliadas fuera aumentando considerablemente hasta alcanzar, en 1903, más de 150 subvenciones.

Los valores “reales”, en tanto, están representados en el Cuadro 1.1., el cual está expresado en moneda constante del año 1920. Esta fórmula permite comparar fidedignamente las cantidades asignadas por el ministerio a los particulares, y, gracias a ello, saber a ciencia cierta si la inyección estatal a los privados fue tan efectiva como muestran los datos "nominales”. Y lo cierto es que, a pesar de que en algunos periodos las subvenciones descendieron con respecto al año anterior, la tendencia "real” a largo plazo fue al alza. En ese sentido, los datos demuestran que el Estado apoyó crecientemente la iniciativa privada, y que, durante esos años, ni siquiera los conflictos curriculares y políticos con los particulares católicos debilitaron la relación económica y de dependencia mutua entre ambos sectores.

${ }^{121}$ Ibídem, p. 537.

122 Véase Lei de Presupuestos de los Gastos Jenerales de la Administracion Pública de Chile para el Año de 1904, 1904. 
CUADRO N ${ }^{\circ}$ 1: $\quad$ PRESUPUESTOS Y SUBVENCIONES A INSTITUCIONES PARTICULARES 1892-1905*

VALORES NOMINALES

\begin{tabular}{lrrrr}
\hline Año & $\begin{array}{c}\text { Presupuesto total } \\
\text { de la nación }\end{array}$ & $\begin{array}{c}\text { Presupuesto } \\
\text { de instrucción } \\
\text { pública }\end{array}$ & $\begin{array}{c}\text { Presupuesto } \\
\text { subvenciones** }\end{array}$ & $\begin{array}{c}\text { Número de } \\
\text { subvenciones } \\
\text { y asignaciones } \\
\text { varias a } \\
\text { establecimientos } \\
\text { particulares *** }\end{array}$ \\
\hline & & & & \\
1892 & & & & \\
1893 & 62.937 .456 & 9.285 .413 & 56.500 & 11 \\
1894 & 48.186 .921 & 7.306 .655 & 72.500 & 13 \\
1895 & 54.807 .771 & 4.540 .843 & 57.500 & 14 \\
1896 & 65.211 .094 & 5.382 .872 & 68.660 & 22 \\
1897 & 87.023 .607 & 5.829 .049 & 98.780 & 23 \\
1898 & 82.265 .829 & 5.787 .653 & 152.980 & 41 \\
1899 & 79.931 .452 & 5.633 .021 & 142.330 & 52 \\
1900 & 65.309 .453 & 5.982 .097 & 197.700 & 60 \\
1901 & 76.415 .001 & 7.850 .958 & 291.000 & 87 \\
1902 & 81.068 .112 & 8.918 .748 & 254.000 & 71 \\
1903 & 100.367 .907 & 10.259 .848 & 497.550 & 146 \\
1904 & 82.023 .854 & 10.660 .331 & 429.450 & 156 \\
1905 & 79.935 .423 & 10.486 .259 & 472.850 & 164 \\
\hline
\end{tabular}

* Se han considerado únicamente los presupuestos en pesos, no en oro.

** Estos montos toman en cuenta las subvenciones a instituciones particulares (escuelas, colegios, sociedades de beneficencia, entre otras), sueldos de visitadores de escuelas, asignaciones para publicaciones de diversas materias, asignaciones para infraestructura de escuelas particulares, etc. Esta nómina registra diferencias casi imperceptibles con las publicadas oficialmente, ya que de éstas hemos expurgados unos pocos casos, que no decían relación directa con el tema en cuestión.

*** Estos montos toman en cuenta las subvenciones a instituciones particulares (escuelas, colegios, sociedades de beneficencia, entre otras), sueldos de visitadores de escuelas, asignaciones para publicaciones de diversas materias, asignaciones para infraestructura de escuelas particulares, etc. Esta nómina registra diferencias casi imperceptibles con las publicadas oficialmente, ya que de éstas hemos expurgados unos pocos casos, que no decían relación directa con el tema en cuestión.

Fuente: Leyes de Presupuestos de los Gastos Jenerales de la Administración Pública de Chile, 1892-1905. 
CUADRO No 1.1: $\quad$ PRESUPUESTOS Y SUBVENCIONES A INSTITUCIONES PARTICULARES 1892-1905

\begin{tabular}{lccc}
\hline \multicolumn{3}{c}{ VALORES REALES } \\
\hline Año & $\begin{array}{c}\text { Presupuesto } \\
\text { total de la nación }\end{array}$ & $\begin{array}{c}\text { Presupuesto } \\
\text { de instrucción pública }\end{array}$ & $\begin{array}{c}\text { Presupuesto } \\
\text { subvenciones }\end{array}$ \\
\hline & & & \\
1892 & 15.082 .343 & 2.225 .158 & 13.540 \\
1893 & 14.082 .055 & 2.135 .283 & 21.187 \\
1894 & 17.840 .882 & 1.478 .123 & 18.717 \\
1895 & 15.909 .289 & 1.313 .238 & 16.751 \\
1896 & 20.033 .011 & 1.341 .859 & 22.739 \\
1897 & 19.657 .582 & 1.382 .971 & 36.555 \\
1898 & 21.421 .928 & 1.509 .671 & 38.145 \\
1899 & 18.861 .183 & 1.727 .612 & 57.095 \\
1900 & 21.760 .414 & 2.235 .688 & 82.867 \\
1901 & 23.236 .895 & 2.556 .418 & 72.805 \\
1902 & 30.342 .753 & 3.101 .709 & 150.417 \\
1903 & 22.998 .774 & 2.989 .064 & 120.414 \\
1904 & 23.411 .259 & 3.071 .186 & 138.487 \\
1905 & 34.266 .637 & 4.663 .846 & 165.625 \\
& & & \\
\hline
\end{tabular}

Fuente: Matías Braun (et al.), "Economía Chilena, 1810-1995: Estadísticas Históricas”, 2000.

¿Quiere decir esto que todos los políticos y educadores de la época aceptaban sin reparos que el Estado subvencionara a las escuelas y colegios particulares? A juzgar por la posición crítica de algunos artículos aparecidos en la Revista de la Asociación de Educación Nacional (RAEN) y en La Revista Pedagójica ( $R P)$, las subvenciones generaban una que otra duda en la comunidad educacional. Lo anterior se debía a tres motivos: en primer lugar, a razones ideológicas, que discutían, al igual como había sucedido con el sistema concéntrico y como ocurriría más explícitamente con el debate de la Ley de Instrucción Primaria Obligatoria, cuál era el papel que cabía al Estado y cuál el que cabía a los particulares en la educación. En segundo término, a diferencias de opinión en temas económicos y presupuestarios; $y$, en tercero, a motivos referentes a la supuesta baja calidad de los centros subvencionados, en comparación con la mayoría de los establecimientos estatales.

Entre 1906 y 1907, la Asociación de Educación Nacional (AEN) presentó al público su impresión sobre la entrega de las subvenciones. El objetivo de dicho organismo era implementar un tipo de enseñanza que 
fomentara lo que, para entonces, comenzaba a reconocerse como la "raza chilena”. En el pensar de su fundador, Carlos Fernández Peña, el Estado Nacional tenía la misión de difundir aquel ethos entre los estudiantes chilenos, dejando de lado a cualquier sector que promoviera, en algún grado, una educación diferente a la del ministerio. Aunque muchos colegios privados adherían a la metodología oficial de instrucción, Fernández creía que sus directores promovían una educación demasiado independiente para ser apoyados económicamente por el Estado, por lo que el régimen de subvenciones debía ser suspendido o cambiado, de forma tal que esos dineros fueran a las aulas fiscales antes que a las particulares.

Para legitimar el rol prescindente del Estado en estas materias, la AEN utilizaba los preceptos constitucionales. De forma perspicaz, aceptaba que el inciso $6^{\circ}$ del artículo 12 hubiera incluido en 1874 la "libertad de enseñanza"123. Sin embargo, al mismo tiempo señalaba que el Estado docente continuaba existiendo y que, en consecuencia, toda institución debía lealtad y subordinación a los dictados del Ejecutivo. De ese modo, si el Estado se desprendía de "una fuerte cantidad de dinero en obsequio de las escuelas primarias particulares, mientras las suyas propias [...] no tienen mobiliario ni material de enseñanza adecuado para las premiosas exijencias de una buena educacion”, era señal de que se estaba cometiendo un atentado contra "el espíritu de la Constitucion"124. Que las instalaciones de las escuelas particulares fueran de mejor calidad que la de las públicas era inconcebible, sobre todo si el Estado era quien auspiciaba tamaña irregularidad:

Hoi dia ocurre que las escuelas privadas atraen a los niños con dádivas de alimento, objetos del vestir, premios, dinero, etc. Esta es una de las causas del despueble de ciertas escuelas públicas. [...] Estas mueren, pues i las privadas surjen i surjirán mas pero no por la calidad de la educacion que suministran, que no puede compararse a la del Estado i que seria sin duda un justo título suyo al mayor aprecio público que ninguna persona honrada sabria negarlos. Este incremento de las escuelas privadas, de cualquier tendencia se alejará despues en abono del sistema de subvenciones i de este modo, lógicamente los fondos del Presupuesto de Instruccion Pública irán año tras año pasando a las escuelas privadas i servirán para matar la educacion nacional i en todo caso para

${ }^{123}$ Véase supra, p. 33.

${ }^{124} R A E N$, año II, número 2, agosto de 1906, sin páginas exactas. 
desviar al Gobierno de la preferente atencion que debe prestarle segun el precepto constitucional ${ }^{125}$.

Cuatro meses después de esta declaración, la AEN volvió a plantear un argumento similar, aunque esta vez fue más lejos, ya que comparó a los sostenedores de colegios particulares con "negociantes sin aspiraciones de cultura nacional i quizá sin moralidad ni condiciones ni elementos para la enseñanza”. Su crítica pretendía desprestigiar un mecanismo de subsidio que atrajera "alumnos hasta asalariadamente, especulando sobre la base de la subvencion a tanto por cabeza"126 y, de ese modo, evitar "el inminente peligro de que la educacion particular se convierta en un negocio"127.

Pero detrás de esta posición no sólo descansaban razones ideológicas y económicas. También lo hacían argumentos que descalificaban la educación de los colegios particulares por no ser suficientemente “científica”. Según los directores de la Asociación, esta constatación demostraba que el Estado no sólo gastaba dinero en centros independientes de la administración ministerial, sino que, además, incentivaba una calidad educacional muy por debajo de las expectativas de la nación ${ }^{128}$. Ni siquiera las escuelas regentadas por misioneros en la Araucanía se salvaban del diagnóstico de la AEN, la cual, en un artículo aparecido en la $R P$, sucesora de la $R A E N$, se quejaba de que la mayoría de los maestros de los indígenas no fueran "graduados en las Escuelas Normales del Estado"129.

Por mucho que el "fin de lucro" no fuera un tema en sí mismo ${ }^{130} \mathrm{y}$ que el aporte de los religiosos del sur era ampliamente reconocido, no cabe

${ }^{125}$ Ibídem. En otra ocasión, Fernández Peña expuso lo siguiente: “Con profundo sentimiento debemos declarar, que después de tanto tiempo trascurrido, no terminen aun las reparaciones ni de una sola de nuestras Escuelas Normales, i que en otras no se inician todavía. Para los liceos no hai todavía decretos. Son terribles los males que trae consigo la lentitud desesperante de las tramitaciones administrativas lo que hace indispensable solicitar del Supremo Gobierno la pronta solucion de estos problemas. Todo con ventaja de la enseñanza privada i en desmedro de la Educación del Estado", en $R A E N$, año III, mayo de 1907, p. 80.

${ }^{126} R A E N$, año II, número 6, diciembre de 1906, sin página exacta.

${ }^{127}$ RAEN, año III, marzo de 1907, p. 51.

${ }^{128}$ Véase $R A E N$, año II, número 2, agosto de 1906, sin páginas exactas.

${ }^{129} R P, 1909$, p. 39.

${ }^{130}$ Véase supra, p. 45. Según Gonzalo Vial, el dinero no era un elemento que movía, por ejemplo, a los sostenedores católicos: “El 'espíritu de lucro’ era un mito respecto a la educación católica, la más resistida por el Partido Laico [Radical]. En buena proporción ella era gratuita. Y la pagada recogía apenas lo indispensable para mantenerse viva y — cuando más - ir ampliándose, y satisfaciendo así, en parte, las crecientes necesidades escolares”, en Vial, Gonzalo: Historia de Chile (1891-1973), 1981, p. 182. 
duda que este tipo de críticas llevó a los gobiernos de turno a enterarse más detenidamente acerca de cómo y a quiénes ayudaba el erario. El 21 de marzo de 1911, el Ejecutivo llegó a la conclusión de que debía crearse una nueva comisión que vigilara la entrega del dinero a las escuelas primarias, no tomando en cuenta otros "factores que la calidad i la seriedad de la enseñanza i el buen pié en que los establecimientos se encuentren”. Es decir, como resultado de los numerosos "denuncios que han llegado al Gobierno sobre abusos cometidos en estos establecimientos i sobre la falta de seriedad de la enseñanza"131, el Estado matizaba su decreto de 1903, en que dejaba plena libertad a "toda persona, natural o jurídica, a quien la lei no lo prohiba" para fundar instituciones primarias ${ }^{132}$. Sin embargo, a la vez el decreto de 1911 mandaba que uno de los miembros de esa comisión fuera el presidente de la Sociedad Santo Tomás de Aquino, una de las principales instituciones de beneficencia privadas ${ }^{133}$.

Esto nos lleva a pensar que, a pesar de las críticas de algunos educadores y políticos chilenos, la relación entre el Estado y los particulares continuó subsistiendo relativamente bien. La información suministrada por los Cuadros 2 y 2.1. y por el Gráfico $N^{\circ} 1$, confirman lo anterior.

El crecimiento de las subvenciones entre 1906 y 1912 está íntimamente ligado al "avance sostenido y acelerado" de la expansión salitrera ${ }^{134}$. En los años siguientes, puede vislumbrarse un estancamiento $\mathrm{y}$, a veces, un retroceso de los tres presupuestos, lo que se debe a las repercusiones internacionales de la Primera Guerra Mundial (1914-1918). Empero, como puede apreciarse en el gráfico, a partir de 1919 la tendencia al alza volvió a hacerse presente. Así, pues, ni siquiera los conflictos en torno a la Ley de Instrucción Primaria Obligatoria — que veremos en el siguiente apartadolograron desarticular el vínculo entre ambos sectores, cuya máxima expresión se vio, nuevamente, en el constante auxilio económico otorgado por el Presupuesto Nacional a los colegios y escuelas privadas durante los años $1906-1920^{135}$.

${ }^{131}$ BLDG, Libro XXX, marzo de 1911, p. 345.

${ }^{132}$ Véase supra, p. 74.

${ }^{133}$ Véase BLDG, Libro XXX, marzo de 1911, p. 345. Este decreto se complementó el 14 de julio de 1912 con la creación de un Consejo de Instrucción Primaria, compuesto, entre otras personas, por el "presidente de la Sociedad Escuelas de Santo Tomas de Aquino”, en BLDG, Libro XXXI, julio de 1912, p. 948.

134 Cariola, Carmen y Osvaldo Sunkel: Un Siglo de Historia Económica en Chile, 1830-1930, 1991, p. 101.

${ }^{135}$ Agradezco la ayuda de los economistas Ignacio Briones y Jorge Camus en la elaboración de los cuadros y gráficos analíticos. 
CUADRO N ${ }^{\circ}$ 2: PRESUPUESTOS Y SUBVENCIONES A INSTITUCIONES PARTICULARES 1906-1920*

\begin{tabular}{|c|c|c|c|c|}
\hline \multicolumn{5}{|c|}{ VALORES NOMINALES } \\
\hline Año & $\begin{array}{l}\text { Presupuesto } \\
\text { total de } \\
\text { la nación }\end{array}$ & $\begin{array}{l}\text { Presupuesto } \\
\text { de instrucción } \\
\text { pública }\end{array}$ & $\begin{array}{c}\text { Presupuesto } \\
\text { subvenciones** } \\
\end{array}$ & $\begin{array}{c}\text { Número de } \\
\text { subvenciones y } \\
\text { asignaciones varias } \\
\text { a establecimientos } \\
\text { particulares } * * * *\end{array}$ \\
\hline 1906 & 123.863 .254 & 17.645 .008 & 744.200 & 243 \\
\hline 1907 & 134.830 .532 & 16.086 .512 & 829.600 & 270 \\
\hline 1908 & 157.715 .666 & 21.487 .715 & $1.403 .700^{* * *}$ & 322 \\
\hline 1909 & 175.084 .403 & 24.508 .168 & 1.917 .700 & 388 \\
\hline 1910 & 197.230 .075 & 26.344 .133 & 1.513 .100 & 357 \\
\hline 1911 & 241.784 .383 & 32.184 .104 & 1.604 .260 & 383 \\
\hline 1912 & 280.894 .117 & 43.240 .682 & 1.914 .020 & 444 \\
\hline 1913 & 257.912 .469 & 37.770 .312 & 1.412 .150 & 406 \\
\hline 1914 & 252.626 .972 & 38.993.906 & 1.272 .550 & 377 \\
\hline 1915 & 184.091 .845 & 32.802 .073 & 895.350 & 361 \\
\hline 1916 & 208.021 .829 & 32.875 .213 & 886.450 & 363 \\
\hline 1917 & 193.432.264 & 33.648.997 & 939.950 & 373 \\
\hline 1918 & 206.994.237 & 37.073 .214 & 849.020 & 381 \\
\hline 1919 & 234.935 .607 & 44.425 .530 & 946.740 & 398 \\
\hline 1920 & 260.850 .397 & 45.006 .960 & 973.750 & 405 \\
\hline
\end{tabular}

* Se han considerado únicamente los presupuestos en pesos, no en oro.

** Estos montos toman en cuenta las subvenciones a instituciones particulares (escuelas, colegios, sociedades de beneficencia, entre otras), sueldos de visitadores de escuelas, asignaciones para publicaciones de diversas materias, asignaciones para infraestructura de escuelas particulares, etc. Esta nómina registra diferencias casi imperceptibles con las publicadas oficialmente, ya que de éstas hemos expurgados unos pocos casos, que no decían relación directa con el tema en cuestión.

*** Cantidad aproximada, pues en las Leyes de Presupuesto de la Nación no aparece la suma total de las subvenciones entregadas durante 1908 .

****Estos montos toman en cuenta las subvenciones a instituciones particulares (escuelas, colegios, sociedades de beneficencia, entre otras), sueldos de visitadores de escuelas, asignaciones para publicaciones de diversas materias, asignaciones para infraestructura de escuelas particulares, etc. Esta nómina registra diferencias casi imperceptibles con las publicadas oficialmente, ya que de éstas hemos expurgados unos pocos casos, que no decían relación directa con el tema en cuestión.

Fuente: Leyes de Presupuestos de los Gastos Jenerales de la Administración Pública de Chile, 1906-1920. 
CUADRO N ${ }^{\circ} 2.2$

\begin{tabular}{lccr}
\hline \multicolumn{3}{c}{ VALORES REALES } \\
\hline Año & $\begin{array}{c}\text { Presupuesto } \\
\text { total de la nación }\end{array}$ & $\begin{array}{c}\text { Presupuesto de } \\
\text { instrucción pública }\end{array}$ & $\begin{array}{c}\text { Presupuesto } \\
\text { subvenciones }\end{array}$ \\
\hline & & & \\
1906 & 41.653 .076 & 5.933 .712 & 250.262 \\
1907 & 52.267 .295 & 6.235 .965 & 321.596 \\
1908 & 78.978 .002 & 10.760 .230 & 702.920 \\
1909 & 84.336 .237 & 11.805 .316 & 923.735 \\
1910 & 97.184 .991 & 12.981 .054 & 745.579 \\
1911 & 119.804 .679 & 15.947 .292 & 794.914 \\
1912 & 149.788 .103 & 23.058 .296 & 1.020 .660 \\
1913 & 152.721 .506 & 22.365 .491 & 836.197 \\
1914 & 162.121 .866 & 25.024 .109 & 816.651 \\
1915 & 137.360 .769 & 24.475 .381 & 668.069 \\
1916 & 147.383 .307 & 23.292 .063 & 628.049 \\
1917 & 139.585 .392 & 24.281 .929 & 678.291 \\
1918 & 147.255 .596 & 26.373 .866 & 603.992 \\
1919 & 205.059 .069 & 38.775 .978 & 826.344 \\
1920 & 260.850 .397 & 45.006 .960 & 973.750 \\
\hline
\end{tabular}

Fuente: Braun, Matías, et al.: “Economía Chilena, 1810-1995”, 2000.

GRÁFICO No ${ }^{\circ}$ 1: $\quad$ PRESUPUESTO NACIONAL, DE INSTRUCCIÓN PÚBLICA Y DE SUBVENCIONES, 1892-1920 (En base logarítmica)

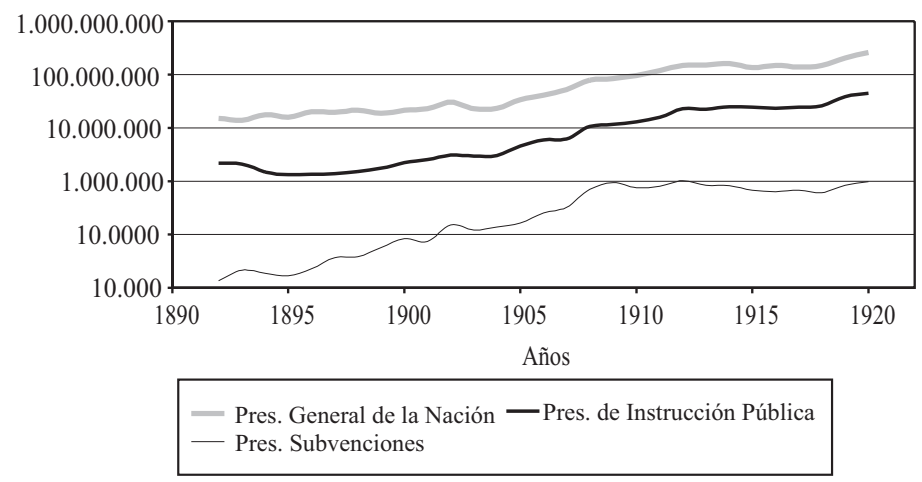




\title{
5. El debate sobre la Ley de Instrucción Primaria Obligatoria
} (1900-1920)

\author{
El Estado, [...] tiene disponibles los fondos públicos; tiene en su \\ mano los dineros con que contribuyen todos los ciudadanos. \\ Es, pues, el Estado una máquina gigantesca, en contra de la \\ cual no se puede batallar; la competencia es, por lo consiguiente, \\ imposible. Establecida la instrucción obligatoria, la actividad \\ privada quedará reducida á cero. Va á suceder con la instrucción \\ obligatoria lo mismo que acontece con las industrias pequeñas, \\ las cuales pueden subsistir mientras no venga una gran fábrica, \\ que concluya con todas ellas. El Estado abrirá escuelas \\ en grande escala; y con ello, lejos de facilitar la difusión de \\ la instrucción privada que, además de ser economía para el fisco, \\ es mejor y más delicada que la oficial, \\ concluirá con el colegio particular. \\ Escuelas Católicas Santo Tomás \\ de Aquino (Año I, N 4, 1 de octubre de 1902).
}

El debate en torno a la Ley de Instrucción Primaria Obligatoria de 1920 es la última arista de la relación sostenida por el Estado y los particulares durante los años de nuestro estudio. Aquella discusión se llevó a cabo en el Congreso Nacional y en la prensa capitalina, y tuvo como protagonistas, por un lado, a los políticos radicales, liberales y democráticos y, por otro, a los conservadores. Ambos sectores se enfrascaron en una larga disputa ideológica con el fin de determinar si los organismos estatales tenían o no el derecho de hacer obligatoria la educación primaria, evidenciándose nuevamente dos posiciones distintas. Al igual que con el sistema concéntrico, el fondo del conflicto residía en la dicotomía "libertad de enseñanza-monopolismo del laicismo estatal”. Sin embargo, el escenario era diferente, ya que, en este caso, se concentraba en la enseñanza de las primeras letras y no en la educación secundaria.

A fines del gobierno de Manuel Montt (1860) se había promulgado una Ley de Instrucción Primaria, en la que se garantizaba que, desde ahí en adelante, el gobierno impartiría educación primaria a todos los que estuvieran en condición de recibirla ${ }^{136}$. No obstante, y pese a la centralización del sistema, la ley permitía que las escuelas privadas estuvieran sometidas "al

136 Véase Campos Harriet, Fernando: Desarrollo Educacional, 1810-1960, 1960, p. 27. 
control estatal sólo en lo referente al orden y la moralidad, quedando en libertad de establecer sus propios programas". Incluso "en el caso de las escuelas católicas se permitía a los párrocos supervigilar la enseñanza religiosa" impartida en sus aulas ${ }^{137}$.

Esta ley rigió sin contratiempos hasta 1900, fecha en que por primera vez se cuestionó su verdadera efectividad. El encargado de hacerlo fue el senador radical Pedro Bannen, quien, al someter "a la consideración legislativa un proyecto de ley para hacer obligatoria la enseñanza primaria”"138, pretendió potenciar definitivamente el rol estatal en la materia. El objetivo del Partido Radical era lograr que el Estado no sólo entregara gratuitamente la educación primaria, sino que tuviera la potestad de hacerla obligatoria. De esa forma, pensaban, ningún niño se quedaría sin aprender los pasos básicos de la enseñanza, ya que se obligaría a los padres a enviar a sus hijos a las escuelas correspondientes.

El de Bannen fue el primero de una serie de proyectos sobre el funcionamiento de la educación primaria en Chile. Con él, el tema se transformó en una "cuestión de actualidad"139, con repercusiones y respuestas inmediatas de los diferentes conglomerados políticos. Los conservadores atacaron la propuesta de Bannen por considerarla atentatoria contra la libertad de enseñanza. Según ellos, la propuesta de los radicales era una señal de las aspiraciones "monopolistas" del Estado, el cual, mediante sus escuelas y colegios primarios, pasaría a controlar el aprendizaje de la gran mayoría de los niños. De concretarse lo anterior, sostenían los católicos, el "espíritu irreligioso y sectario" de los radicales se propagaría, ya no sólo entre los secundarios (a través del sistema concéntrico) sino, más peligroso todavía, entre los estudiantes primarios.

La $R C$ consideró que el proyecto de Bannen era, además de "irreligioso en sus consecuencias", "injusto en su esencia” y "odioso y perjudicial en la práctica"140. Entre julio y agosto de 1902, salieron a la luz una serie de artículos destinados a contradecir política y filosóficamente al Partido Radical. En opinión de L.R.L. [sic], autor de aquellas publicaciones, el proyecto era injusto "porque es contrario al derecho natural, fuente y limitación de las atribuciones del Estado en la sociedad civil”. Siguiendo a Tomás de Aquino, sostenía que la educación era un derecho natural de los hijos, cuyo ejercicio debía descansar en "la sociedad doméstica", es decir, en los

${ }^{137}$ Baeza, Andrés: "La Dimensión Educacional de la Crisis del Centenario en Chile...”, 2006, p. 49.

138 Véase Campos Harriet, Fernando: Desarrollo Educacional, 1810-1960, 1960, p. 28.

${ }^{139} R C$, número 23, 5 de julio de 1902, p. 520.

${ }^{140}$ Ibídem. 
padres de familia ${ }^{141}$. Estos podían elegir cómo y dónde educar a sus hijos, y ningún cuerpo administrativo podía sobrepasar ese derecho.

A su vez, uno de los argumentos utilizados por los radicales para justificar su posición frente a la obligatoriedad de la enseñanza, descansaba en el papel que, supuestamente, cabía al Estado en la extensión del "bien común” en la sociedad civil. Bannen y sus correligionarios creían que la instrucción primaria era "necesaria para el bien común" y que, en consecuencia, los gobiernos podían y debían "imponerla obligatoriamente"142. Los conservadores, por su parte, también adherían a la teoría del "bien común”, pero no creían que aquél tuviera que regirse por las decisiones unilaterales del Estado, sino por el derecho natural depositado por Dios en los padres de los futuros estudiantes. De ahí que su máxima aspiración fuera frenar "á los mandocillos de departamento, verdaderos sultanes por su arbitrariedad y despotismo"143.

En ese sentido, cuando la $R C$ declaraba que el proyecto de Bannen era "odioso y perjudicial en la práctica” se refería a que la ley podía conllevar abusos tremendos de parte de la autoridad estatal (gobernadores, subdelegados y visitadores fiscales), la cual obligaría a los padres de más bajos recursos a enviar a sus hijos a una escuela a aprender "una lección de abecé”, mientras aquéllos quedaban abandonados a su suerte en las labores del campo o del taller ${ }^{144}$. El "despotismo" del gobierno, entonces, debía combatirse con todas las herramientas, incluso con el sarcasmo y la ficción. Al final del documento que hemos venido citando, encontramos una poesía que, vista desde hoy, es de dulce y agraz sobre la Ley de Instrucción Primaria Obligatoria y sus "nefastas" consecuencias:

Érase Micho un gato muy hermoso,

Alegre y juguetón como ninguno;

Tan bravo y animoso

Que jamás lo burló ratón alguno.

Era también discreto, inteligente,

${ }^{141}$ Ibídem. Las cursivas son del original. Las alusiones a Tomás de Aquino son directas: "Santo Tomás con admirable sabiduría y claridad expone los derechos que corresponden á los padres en la formación de sus hijos. 'Al que produce una cosa, dice, corresponden perfeccionarla. Dios, primer padre y autor de cuanto existe, tiene dominio perfecto y absoluto sobre todo: de Él emana toda autoridad, como principio universal del ser, pero los padres son el principio particular de la existencia de sus hijos, y, después de Dios, les deben á ellos el beneficio de la vida””, en ibídem, p. 537.

${ }^{142}$ Citado en ibídem, p. 523.

${ }^{143}$ Ibídem, pp. 525-526.

${ }^{144}$ Ibídem. 
Sumiso y obediente,

En fin, una lindura;

Y por eso Bertina, que era su ama,

Lo amaba con locura.

Un día ésta leyó que allá en Europa

Cierta curiosa ley, más bien capricho,

Obliga la instrucción á todo bicho,

$\mathrm{Y}$, viendo que es de la gatuna tropa

Dechado fiel su Micho,

Lo coge entre sus brazos y, por fuerza,

$\mathrm{Y}$ á pesar que perturba al vecindario,

Lección le empieza á dar de Silabario.

Protesta el pobre Micho,

Con súplicas primero

Y en segunda con uñas y con dientes:

-"No me gusta, no quiero,

Ni nunca hicieron tal mis ascendientes.

No me he domesticado

Para leer y escribir como los hombres;

Y si vivo á tu lado

(De lo cual no te asombres)

Es sólo para hacerte compañía

Y cuidarte la casa noche y día”.

-Así será, respóndele Bertina;

Pero el caso es que aquí yo sola mando:

Tú seguirás la moda peregrina,

Y, sin lugar á excusa dilatoria,

Ni al cómo, dónde, ó cuándo,

Desde hoy quedas sujeto

Á la Instrucción Primaria Obligatoria!

-Y ¿por qué? -Porque sí: ¿̇me entiendes, Micho?

Conque, callar y obedecer. He dicho.

Venció el gato la horrible repugnancia

$\mathrm{Y}$ al estudio se dió con tal constancia,

Que al fin, con su talento y su paciencia,

Fué un pozo gatólico de ciencia.

Las negociaciones mil del ateísmo,

La sin igual razón del socialismo,

El moderno anarquismo,

Todo esto y mucho más aprendió pronto 
El estudioso Micho,

Que, según queda dicho,

Pecaba de sagaz, que nó de tonto $[\ldots]^{145}$.

El poema es una prueba fehaciente de lo que pensaba la $R C$ respecto de la obligatoriedad de la instrucción primaria. Al controlar el Estado más escuelas que los privados, un número significativo de niños se vería inmerso en el "ateísmo", el "socialismo" y el "anarquismo" de los educadores estatales, quienes, por lo demás, muchas veces estaban vinculados al Partido Radical ${ }^{146}$. Por ello, no es de extrañar que la $R C$ se autoproclamara la voz semi-oficial del Partido Conservador para atacar una y otra vez al "radicalismo"147, y que la discusión ideológica estuviera teñida, preferentemente, por las coyunturas políticas que se daban en el Congreso y en la prensa.

Por esta razón, y como decíamos al principio de este apartado, el debate debe ser insertado en la dicotomía libertad de enseñanza-monopolismo estatal y, por consiguiente, en la antítesis laicismo estatal-Iglesia. Ya vimos que los conservadores no querían que se consumara la separación de ambos poderes; más bien exigían que el Estado reafirmara su catolicismo y que las doctrinas contrarias a la religión no tuvieran cabida en las escuelas fiscales. Los artículos de la $R C$ parecían señalar que la derrota ante la puesta en práctica del sistema concéntrico en los colegios secundarios era una razón más que poderosa para luchar porque los niños del país recibieran una enseñanza primaria inspirada en los principios del catolicismo.

A la $R C$ se le agregaba la Revista Escuelas Católicas Santo Tomás de Aquino (RECSTA), cuyos redactores pedían que el Estado no se inmiscuyera en la enseñanza de los más de tres mil niños que acudían a sus escuelas ${ }^{148}$. Es cierto que en su cruzada recibían la subvención del erario;

145 Ibídem, pp. 565-566.

${ }^{146}$ El propio Bannen había fundado la SIP de Concepción en 1883 y tenía vínculos directos con la SIP de Santiago, en Armando de Ramón, Santiago, 1999, tomo I, p. 135.

${ }^{147}$ El 19 de julio de 1902, la $R C$, número 24, p. 579, anotaba: “¡Ojalá el único móvil de los factores de esta ley fuera el ardiente deseo de ilustrar á nuestro pueblo, difundiendo cada vez más las luces del saber! Santo y laudable pensamiento sería indudablemente. Pero por desgracia la más triste experiencia confirma la verdad de nuestro aserto. Lo que actualmente pasa en la mayor parte de los Colegios y Escuelas fiscales de los cuales se ha apoderado el radicalismo, convertidos en centros de la más abierta y descarada propaganda antirreligiosa, arrebatan la fe, el más precioso de los dones del Altísimo, de los inocentes corazones de la juventud que tiene la desgracia de caer en esos establecimientos que se titula de educación... ¿no es la más elocuente confirmación práctica del inmenso mal que lamentamos?”.

${ }^{148}$ Véase RECSTA, año I, número 3, 1 de agosto de 1902, p. 75. 
sin embargo, eso no implicaba que tuvieran que depender de los organismos fiscales, menos aún si éstos despotricaban contra la educación impartida por el cristianismo. En una extensa editorial del $1^{\circ}$ de octubre de 1902 se lee:

La instrucción obligatoria nos provoca á una lucha de desigualdad irritante, hiere la libertad individual y ciega una de las inclinaciones más nobles del espíritu humano, como es la de dedicarse á la educación de la niñez. Creemos que no andamos desacertados al decir que la instrucción obligatoria de hecho no será sino instrucción oficial obligatoria. [..] El malhadado proyecto presenta [...] [un] aspecto que lo hace extremadamente odioso; y es la mala y desmoralizadora educación que da el Estado. [...] Para nadie es misterio lo que sucede ordinariamente en las escuelas fiscales. Revueltos allí niños de toda índole y carácter; con escasa ó ninguna vigilancia de los superiores, son las tales escuelas la mejor preparación para que el niño pierda la inocencia y adquiera hábitos detestables. [...] Si á esto se agrega que muchos maestros no son espejo de buenas costumbres y rectitud de conciencia, se comprenderá por qué de las escuelas públicas salen tantos alumnos, que son un verdadero peligro social. Si la escuela no es atendida como se debe, se trueca en foco de maldad; si el maestro no predica con el ejemplo, no comprende su delicada misión y se torna en corruptor de la niñez. ¿ No es cruel que se obligue á los padres á entregar sus pequeñuelos en manos de tales educadores? Tal ausencia de moralidad en las escuelas públicas, es consecuencia inmediata de la falta de religión. Es absurdo, es ridículo, procurar introducir buenas costumbres entre los niños, si no hay base religiosa. [...] Y que el espíritu que informa la instrucción oficial no es religioso, se manifiesta en el hecho de que los párrocos no tienen ninguna ingerencia en las escuelas públicas; la clase de catecismo es casi de pura fórmula. Tienen, pues, razón los radicales para batir palmas en honor del proyecto presentado por el senador señor Bannen; con el cual el radicalismo procura abrirse anchísimo horizonte de futura grandeza ${ }^{149}$.

El objetivo de la RECSTA era impugnar al Estado docente y detener en alguna medida el paso avasallador del laicismo. En su pensar, la educación impartida por sus escuelas demostraba que no "eran enemigos de la ilustración del pueblo", y que sus ataques contra "la instrucción obligato-

${ }^{149}$ RECSTA, año I, número 4, 1 de octubre de 1902, pp. 106-109. Las cursivas son del original. 
ria, no ha sido por ser instrucción, sino por ser obligatoria”150, es decir, estatal.

Las opiniones de la $R C$ y de la RECSTA dieron resultados más o menos inmediatos, ya que, después de 1902, el debate bajó en intensidad, y no fue sino hasta siete años después que la idea de hacer obligatoria la instrucción primaria volvió a la palestra. Esta vez, el encargado de formular el nuevo proyecto fue el radical Enrique Oyarzún, cuyo propósito era reducir el porcentaje de la población que "aún se encontraba sumada en el alfabetismo" 151 , que alcanzaba el 60\%. Aprovechando que el Centenario se avecinaba, diputados de la Alianza Liberal pusieron en tabla la discusión del proyecto el 2 de junio de 1910, día en el cual Manuel Rivas Vicuña, miembro del Partido Liberal, solicitó que la Ley se discutiera en sesiones ordinarias y extraordinarias. Con ello, pensaba Rivas Vicuña, el debate podría tomar un curso dinámico y la sanción del proyecto se concretaría en un tiempo razonable.

Sin embargo, el Partido Conservador no estaba dispuesto a que esto sucediera. Conocedores de la lentitud del sistema parlamentario, conservadores como Alfredo Barros Errázuriz lograron copar las sesiones ordinarias de la Cámara de Diputados y reiterar una y otra vez su posición frente al proyecto de la Alianza. Barros Errázuriz explicó que su Partido estaba a favor de que todos los niños chilenos recibieran educación, pero eso no quería decir que aceptara "la obligación que se quiere imponer a los padres de familia para que envien a sus hijos a determinados colejios fiscales"152. De una u otra forma, Barros Errázuriz pensaba que en los planes de Oyarzún se encontraba el "objeto soterrado de homogeneizar las conciencias de los niños en función de una educación laica y que estableciera sus propias verdades como parte del programa de estudios”153.

Y lo cierto es que Barros Errázuriz no estaba errado en su diagnóstico. Malaquías Concha, diputado del Partido Demócrata y gran impulsor del “Proyecto Oyarzún”, defendía que esta ley impulsara una educación laica y neutra, y que se abstuviera de imprimir “a los alumnos una tendencia religiosa determinada” ${ }^{154}$. En este proyecto descansaba, entonces, la antigua aspiración de radicales y liberales de secularizar totalmente los espacios públicos del país, y avanzar, aunque sólo fuera en alguna medida, en la

${ }^{150}$ RECSTA, año I, número 5, 1 de diciembre de 1902, p. 141.

151 Nuestro análisis sobre el "Proyecto Oyarzún" está basado en la interpretación de Baeza, Andrés: "La Dimensión Educacional de la Crisis del Centenario en Chile...”, 2006, pp. 90-114.

${ }^{152}$ Citado en ibídem, p. 93.

${ }^{153}$ Ibídem.

${ }^{154}$ Citado en ibídem, p. 94. 
concreción de la separación Iglesia-Estado. Según los aliancistas, de ese modo iría tomando cuerpo un nuevo tipo de sociedad, ya no subordinada a dogmas religiosos, sino a preceptos "modernizadores" inspirados en el progreso material e industrial que podía producir la masificación de la escolari$\mathrm{dad}^{155}$. Promover una demanda estudiantil orientada a la industria y equilibrarla con la cada vez más elevada oferta de escuelas y colegios, parecía ser la consigna de la Alianza Liberal ${ }^{156}$.

El debate se extendió por los meses de junio y julio de 1910. Los conservadores lograron dilatar la cuestión, hasta el punto que incluso algunos de los correligionarios de Barros Errázuriz estuvieron dispuestos a "buscar una alternativa para evitar una prolongación excesiva de esta materia y profundizar las odiosidades” ${ }^{\text {"157 }}$. Ese fue el caso de Guillermo Subercaseaux, quien incentivó a los diputados Alejandro Huneeus y Abraham Ovalle a "gestionar con los grupos liberales la modificación de ciertos puntos y procurar llegar á un acuerdo sobre la materia”"158. Al igual como sucedería con el sistema concéntrico pocos años después, una corriente más proclive al consenso se abría paso en las filas del Partido Conservador.

El 10 de julio de 1910 se publicó en El Mercurio de Valparaíso un proyecto de transacción elaborado por Huneeus. Su objetivo era "armonizar algunas de las disposiciones más controversiales para los conservadores, de manera tal de dejar a todos los sectores políticos conformes”159. Así, por ejemplo, Huneeus establecía que los niños que vivieran alejados de las escuelas públicas no estarían obligados a acudir a las aulas fiscales a recibir

${ }^{155}$ Véase ibídem, pp. 98-99.

${ }^{156}$ Como dicen María Loreto Egaña y Mario Monsalve, la oferta educacional siempre sobrepasó a la demanda estudiantil. Analizando los planes educacionales de Domingo Faustino Sarmiento, uno de los grandes reformadores de la educación chilena de mediados del siglo XIX, llegan a la siguiente conclusión: "Sarmiento lo que planteaba era una estrategia civilizadora en lo sustancial, en cuya base él ubicaba la instrucción como el instrumento que haría posible con posteridad, cuando se introduzcan 'los medios mecánicos', que éstos puedan ser operables por sujetos ya calificados. Esta secuencia pasará a ser la lógica dominante con la que se dirigirá posteriormente el desarrollo de las políticas de escolarización del país, que se puede sintetizar en que la oferta educativa se hace prevalecer e incrementar independiente de la demanda de mano de obra calificada que requiere el sector productivo, dando lugar a una situación de permanente desequilibrio. Esto permite afirmar que por esta causa, en el desenvolvimiento de la educación nacional, la demanda siempre ha quedado por debajo de la oferta”, en Egaña, María Loreto y Mario Monsalve: “Civilizar y Moralizar en la Escuela Primaria Popular”, 2006, p. 122.

${ }^{157}$ Baeza, Andrés: "La Dimensión Educacional de la Crisis del Centenario en Chile...”, 2006, pp. 99-100.

${ }^{158}$ Citado en ibídem, p. 100.

${ }^{159}$ Ibídem, p. 102. 
la instrucción primaria, y que aquélla podría difundirse en sus casas o en establecimientos privados. "Con esto — dice Andrés Baeza- se buscaba salvaguardar el derecho que tenían los padres de elegir la educación para su[s] hijo[s]", además de fomentar "el ideal expansivo de la instrucción primaria” ${ }^{160}$. Por primera vez, la libertad de enseñanza y la difusión de las primeras letras tenían cabida al mismo tiempo en un proyecto de esta naturaleza.

A pesar de que las ideas de Huneeus pasaron desapercibidas incluso entre los propios conservadores, el espíritu transaccional fue el que finalmente imperó cuando, a fines de julio de 1910, llegó el momento de tomar una decisión sobre el tema. No obstante, en este caso la posición conciliadora provino de los propios diputados del Partido Liberal, quienes, en una decisión audaz pero pragmática, "propusieron una salida intermedia que buscara concretar un proyecto basado en los consensos que unían a ambos sectores más que acentuar los disensos”"161. Arturo Alessandri, uno de estos diputados, cerró el debate en torno al Proyecto Oyarzún señalando que "leyes tan trascendentales deben ser resultante de todas las opiniones, todos la cumplirán si cuentan con la benevolencia i aceptación del primero i último habitante de la república"162. De esta manera, se frustró otra vez la tramitación de una ley de instrucción primaria obligatoria.

La oposición de los conservadores evidenció lo difícil que podía llegar a ser la puesta en práctica de un proyecto específico si no se contaba con suficientes votos en el Congreso. Quizás por esta razón es que el debate volvió a desaparecer hasta 1917, fecha en que nuevamente los radicales plantearon la posibilidad de hacer obligatoria la educación primaria. Sin embargo, en esta ocasión los radicales no estaban solos en su lucha, sino que contaban con el apoyo irrestricto de los liberales e, incluso, de algunos miembros del Partido Conservador. ¿Qué había sucedido? ¿Por qué un grupo pequeño pero importante de católicos estaba dispuesto, ahora, a aprobar esta conflictiva ley?

El cambio de los conservadores tiene dos explicaciones. En primer lugar, el ascenso de una nueva generación de líderes permitió ampliar los horizontes y bajar en alguna medida el doctrinarismo de los primeros años. Esto quedó de manifiesto en las transacciones cerradas por algunos sectores de la Iglesia después de 1910 en determinadas áreas del acontecer nacional. En segundo lugar, y como incentivo a lo anterior, la lentitud histórica

\footnotetext{
160 Ibídem.

${ }^{161}$ Baeza, Andrés: "La Dimensión Educacional de la Crisis del Centenario en Chile...”, 2006, p. 111.

${ }^{162}$ Citado en ibídem.
} 
del parlamentarismo chileno terminó por agotar a muchos de los políticos de la Alianza Liberal, quienes vieron en el consenso la posibilidad de aprobar los proyectos de ley que continuaban reposando aletargados en el Congreso. Fue esta combinación de elementos la que abrió las puertas a que la instrucción primaria obligatoria volviera a discutirse, y ya no desde polos tan opuestos.

Los propiciadores del nuevo proyecto fueron, además de los radicales, el liberal Manuel Rivas Vicuña, arriba mencionado, y los conservadores Rafael Gumucio y Tomás Menchaca. A pesar de provenir de mundos distintos, estos tres políticos fueron capaces de olvidar sus rencillas ideológicas y construir una solución que dejara satisfechos a todo el espectro. El punto más controversial continuaba siendo el referente a la obligatoriedad, ya que, según los conservadores, ella daba paso a que en las escuelas primarias se implementara "como obligatoria la enseñanza laica"163. Por ello, el gran objetivo de Gumucio y Menchaca fue conseguir que Rivas Vicuña los acompañara en una modificación al proyecto de los radicales, en la que se garantizaba que el catolicismo no sería expulsado de las aulas fiscales. Luego de una negociación encabezada por el propio Rivas Vicuña y por el ministro del interior del presidente Juan Luis Sanfuentes, Ismael Tocornal, los liberales aceptaron la propuesta de los conservadores, y la ley fue votada favorablemente por la Cámara ese mismo año de $1917^{164}$.

La negociación en el Senado duró otros dos años. Con el fin de acelerar la tramitación, en 1918 los profesores organizaron un Comité Central Pro Instrucción Primaria Obligatoria ${ }^{165}$. Su creación fue una complementación del libro que publicara Darío Salas en 1917, El Problema Nacional. Bases para la Reconstrucción de Nuestro Sistema Escolar Primario, cuyas páginas se convertirían en el gran soporte intelectual del proyecto aprobado por los diputados. Del mismo modo, no deja de ser interesante que la $R C$ se haya sumado a estas iniciativas, aunque siempre desde su punto de vista. En un artículo del 2 de agosto de 1919, el presbítero Francisco J. Cavada se mostraba confiado en que la ley sería aprobada por el Senado y que la ciudadanía podría contar con una instrucción primaria obligatoria que no fuera necesariamente laica:

${ }^{163} R C$, número 432, Santiago, 2 de agosto de 1919, p. 172.

164 Véase Rivas Vicuña, Manuel: Historia Política y Parlamentaria de Chile, 1964, tomo II, pp. 44-46 y Blanco Viel, Óscar: "Ley de Instrucción Primaria Obligatoria”, 1921, pp. 28-30.

165 Véase Soto Sepúlveda, Maximiliano: "Políticas Educacionales en Chile durante el Siglo XX”, 2004, p. 4. 
Parece, pues, que la elección no puede ser dudosa, y que el elemento más sano y moderado del país, aun dentro del Liberalismo doctrinario, nos acompañará en esta cruzada que se inicia en el país y se decidirá en el Senado en pro de la enseñanza obligatoria, pero nó laica ${ }^{166}$.

Finalmente, en septiembre de 1919 los senadores aprobaron la ley, no sin antes introducir un par de modificaciones a lo que la Cámara Baja había sancionado en $1917^{167}$. Se publicó en el Diario Oficial de 26 de agosto de 1920 con el número 3.654, lleva la firma del presidente Sanfuentes ${ }^{168} \mathrm{y}$ en su versión original contiene ocho títulos. En ellos, se establece que la obligatoriedad escolar duraría cuatro años, es decir, de los 7 a los $13^{169}$, y que, entre otras cosas, los niños debían aprender lectura, escritura, geografía, idioma patrio y doctrina cristiana ${ }^{170}$. Por otro lado, el título III clasifica las obligaciones de las escuelas particulares y regula, por última vez en el periodo de nuestro estudio, los criterios a los que debían atenerse los agentes estatales y los sostenedores privados en materia de subvenciones.

En cuanto a las obligaciones, es importante destacar que el artículo 38 mandaba a que los dueños de propiedades agrícolas avaluadas en más de "quinientos pesos, con una extensión no menor de dos mil hectáreas cuadradas, con una población escolar mayor de veinte alumnos” mantuvieran, "por su cuenta, una escuela elemental”. De igual forma, el precepto 40, sostenía que "toda empresa industrial, minera, salitrera, boratera, fábricas, etc., en cuyos establecimientos se ocupen más de doscientos obreros i que tenga una población escolar de veinte alumnos, a lo menos, estará obligada a fundar i sostener una escuela elemental”. Por mucho que, en nuestro tiempo, esa imposición pueda ser considerada atentatoria contra la propiedad privada, en el contexto de esos años debe ser comprendida como un elemento más de la confianza depositada por el Estado en los particulares al

${ }^{166} R C$, número 432, Santiago, 2 de agosto de 1919, p. 180.

167 Véanse las sesiones ordinarias y extraordinarias de la Cámara de Diputados, entre el 12 de noviembre y el 15 de diciembre de 1919, en Boletín de las Sesiones Ordinarias y Extraordinarias de la Cámara de Diputados.

168 El interés de Sanfuentes por acelerar la tramitación del proyecto de ley quedó de manifiesto, entre otros documentos, en su Mensaje Presidencial del $1^{\circ}$ de junio de 1919. Véase Juan Luis Sanfuentes, Mensaje Leído por S.E. el Presidente de la República en la Apertura de las Sesiones Ordinarias del Congreso Nacional, 1919, p. 15.

${ }^{169}$ Véase Beyer, Harald: “Entre la Autonomía y la Intervención: Las Reformas de la Educación en Chile”, 2001, p. 650.

${ }^{170}$ Véase el artículo 16 de la Ley de Instrucción Primaria Obligatoria de 1920, en www.memoriachilena.cl 
momento de fundar y sostener escuelas, sobre todo si ellas debían ser “mantenidas” por los dueños de las propiedades.

Algo parecido podemos decir de las subvenciones. Los artículos 42 a 45 identifican quiénes podían recibir la ayuda estatal y cuáles eran las condiciones a las que debían atenerse. Las escuelas municipales que no tuvieran "rentas suficientes" y los propietarios agrícolas e industriales obligados a sostener un establecimiento en su propiedad, podrían contar con "una subvención anual hasta de veinticinco pesos por alumnos de asistencia media”, siempre y cuando el Consejo de Educación Primaria lo considerara pertinente. Los demás centros particulares tendrían derecho al mismo auxilio si cumplían cinco condiciones: que fueran gratuitas; que impartieran “como mínimum la enseñanza que percibe el artículo 16” (aunque la enseñanza de la doctrina cristiana no sería requisito); que funcionaran en un lugar "higiénico"; que tuvieran una asistencia media de 35 alumnos en los distritos rurales; y que funcionaran, "por lo menos, cuatro horas diarias durante ciento ochenta días en el año”171. Es decir, en esta ley, las subvenciones cubrían a la oferta educacional (a través de una cierta cantidad de dinero por alumnos), y la gratuidad apoyaba decididamente a la demanda estudiantil.

\section{Consideraciones Finales}

A lo largo de estas páginas hemos visto aspectos importantes de la relación entre el Estado y los particulares en la educación primaria y secundaria, entre los años 1888-1920. Nuestro principal objetivo ha sido reconstruir los espacios — públicos y privados - en que se relacionaban los diferentes actores de la enseñanza nacional y, con ello, confirmar que el origen del vínculo entre ambos sectores es anterior a lo que comúnmente se cree. Es cierto que el poder estatal era bastante hegemónico en muchas de las áreas analizadas. Sin embargo, también es efectivo que los privados jugaban un papel de relevancia en el mercado escolar; no sólo en el sostenimiento de escuelas y colegios, sino también en la discusión ideológica llevada a cabo en la prensa y en el Congreso Nacional.

Esas dos fuentes corroboran que el gran causante de las diferencias entre los particulares católicos y los agentes estatales era la relación IglesiaEstado y sus posiciones antagónicas ante el avance de la laicización de la educación. Ahora bien, ¿eliminó aquel antagonismo cualquier posibilidad de

171 Toda la información correspondiente al Título III de la Ley puede encontrarse en ibídem, pero también en RIP, año XL, número 7 y 8, Santiago, septiembre y octubre de 1920, pp. 444-447. 
negociación? Como vimos, en ciertas ocasiones el pragmatismo podía ser más fuerte que las posturas ideológicas extremas, ya fuera en materia curricular, legislativa o económica, y que, por lo tanto, las doctrinas — como el liberalismo - podían ser instrumentales, esto es, coyunturales y conciliadoras.

Con todo, no cabe duda que la lucha protagonizada por radicales, liberales y conservadores en esas décadas fue la antesala de más de alguna de las reformas educacionales de la segunda mitad del siglo XX. En ese sentido, no debe extrañar que un gobierno católico como el de Eduardo Frei Montalva pusiera término a la "examinación oficial", como tampoco que la influencia de los políticos decimonónicos —en su vertiente estatista o religiosa - se proyectara sobre más de algún educador, economista o político desde 1970 hasta la fecha.

\section{REFERENCIAS BIBLIOGRÁFICAS}

Anderson, Benedict: Comunidades Imaginadas. Reflexiones sobre el Origen y la Difusión del Nacionalismo. Buenos Aires: Fondo de Cultura Económica, 2000.

Baeza, Andrés: "La Dimensión Educacional de la Crisis del Centenario en Chile. Modernización, Nacionalismo y Reforma”. Tesis de Licenciatura para optar al grado de Licenciado en Historia en la Universidad Católica de Chile, 2006. Inédita.

"La Muerte de José Manuel Balmaceda. ...El Sacrificio Es lo Único que Queda al Honor del Caballero". En varios autores, XIX. Historias del Siglo XIX Chileno. Santiago: Ediciones B, 2006.

Barros Arana, Diego: Historia General de Chile, tomo XV. Santiago: Editorial Universitaria, DIBAM, 2005.

- Un Decenio de la Historia de Chile, (1841-1851), tomo I. Santiago: Ediciones del Instituto de Historia de la Pontificia Universidad Católica de Chile, 2003.

Beyer, Harald: "Entre la Autonomía y la Intervención: Las Reformas de la Educación en Chile”. En Felipe Larraín y Rodrigo Vergara (editores), La Transformación Económica de Chile. Santiago: Centro de Estudios Públicos, 2001.

Blanco Viel, Óscar: "La Ley de Instrucción Primaria Obligatoria”. En Memoria de Prueba para optar al grado de Licenciado en la Facultado de Leyes y Ciencias Políticas de la Universidad de Chile. Santiago: Imprenta Cervantes, 1921.

Boletín de las Sesiones Ordinarias y Extraordinarias de la Cámara de Diputados. Santiago: 1919.

Boletín de Leyes y Decretos del Gobierno (BLGG). Libros XXX, XXI y LXX.

Braun, Matías, et al.: “Economía Chilena, 1810-1995: Estadísticas Históricas”. En Documento de Trabajo, Número 187, Pontificia Universidad Católica de Chile, Instituto de Economía, Santiago, 2000.

Campos Harriet, Fernando: Desarrollo Educacional, 1810-1960. Santiago: Editorial Andrés Bello, 1960. 
Cariola, Carmen y Osvaldo Sunkel: Un Siglo de Historia Económica en Chile, 18301930. Santiago: Editorial Universitaria, 1991.

Censo General de la República de Chile de 1907. En www.memoriachilena.cl

Cifuentes, Abdón: Memorias, tomo I. Santiago: Editorial Nascimento, 1936.

Collier, Simon: Chile: La Construcción de una República, 1830-1865. Política e Ideas. Santiago: Ediciones Universidad Católica, 2005.

Chile: The Making of a Republic, 1830-1865. Politics and Ideas. United States of America: Cambridge University Press, 2003.

Constitución Política de Chile de 1833. En www.memoriachilena.cl.

Cruz, Nicolás: El Surgimiento de la Educación Secundaria Pública en Chile. 1843-1876

(El Plan de Estudios Humanista). Santiago: DIBAM, 2002.

De Ramón, Armando: Biografías de Chilenos, 1876-1973, tomo I. Santiago: Ediciones Universidad Católica de Chile, 1999.

Egaña, María Loreto y Mario Monsalve: “Civilizar y Moralizar en la Escuela Primaria Popular”. En Rafael Sagredo y Cristián Gazmuri (editores), Historia de la Vida Privada en Chile, volumen II. Santiago: Editorial Taurus, 2006.

Jaksic, Iván: Academic Rebels in Chile. The Role of Philosophy in Higher Education and Politics. United States of America: State University of New York Press, 1989.

Andrés Bello: La Pasión por el Orden. Santiago: Editorial Universitaria, 2001.

Labarca, Amanda: Historia de la Enseñanza en Chile. Santiago: 1953.

La Revista Católica (RC). Santiago, años 1892-1920.

La Revista Pedagójica (RP). Santiago, años 1909-1910.

Ley de Instrucción Primaria Obligatoria de 1920. En www.memoriachilena.cl

Leyes de Presupuestos de los Gastos Jenerales de la Administración Pública de Chile. Años 1890-1920. Santiago: Imprenta Nacional.

Moscoso, Pablo: “La Cuestión del Sacristán: Historia en Diez Actos”. En varios autores, XIX, Historias del Siglo XIX Chileno. Santiago: Ediciones B, 2006.

Pérez Rosales, Vicente: Recuerdos del Pasado. Santiago: Ediciones B, 2006.

Revista de la Asociación de Educación Nacional (RAEN). Santiago, años 1905-1907.

Revista de Escuelas Católicas Santo Tomás de Aquino (RECSTA). Varios números, 1902. Revista de Instrucción Primaria (RIP). Años 1899-1920.

Rivas Vicuña, Manuel: Historia Política y Parlamentaria de Chile, tomo II. Santiago: Ediciones de la Biblioteca Nacional, 1964.

Sanfuentes, Juan Luis: Mensaje leído por S.E. el Presidente de la República en la apertura de las Sesiones Ordinarias del Congreso Nacional. Santiago: Imprenta Fiscal de la Penitenciaría de Santiago, 1919.

Serrano, Sol: "De Escuelas Indígenas sin Pueblos a Pueblos sin Escuelas Indígenas: La Educación en la Araucanía en el siglo XIX”. En Historia, número 29, Santiago, 1995-1996.

- Universidad y Nación. Chile en el Siglo XIX. Santiago: Editorial Universitaria, 1993.

Soto Sepúlveda, Maximiliano: "Políticas Educacionales en Chile durante el siglo XX”. En Revista Mad, número 10, Santiago, mayo de 2004.

Vial, Gonzalo: Historia de Chile (1891-1973), volumen I, tomo I. Editorial Santillana, Santiago, 1981. 